VOLUMINA JURASSICA, 2021, XIX: 1-20

DOI: 10.7306/VJ.19.1

\title{
Carbon, oxygen and strontium isotope composition of Plattenkalk from the Upper Jurassic Wattendorf Konservat-Lagerstätte (Franconian Alb, Germany)
}

\author{
Wolfgang BLENDINGER ${ }^{1}$, Matthias MÄUSER ${ }^{2}$
}

Key words: Jurassic, Plattenkalk, isotopes, correlation, aged seawater.

\begin{abstract}
The oldest Jurassic (Kimmeridgian) Plattenkalk occurs in Wattendorf on the northern Franconian Alb (southern Germany). It is a $15 \mathrm{~m}$ thick alternation of laminated dolomite and limestone, interbedded with carbonate debris layers in a depression $\sim 2 \mathrm{~km}$ across and a few tens of metres deeper than the surrounding microbial-sponge reefs. The Plattenkalk overlies a few tens of metres of microbialsponge biostrome facies and bedded, micritic basinal limestone. The bulk-rock stable isotopes of the micritic basinal facies gradually change from normal marine $\left(\delta^{13} \mathrm{C} \sim+2 \%\right.$, $\delta^{18} \mathrm{O} \sim-2 \%$ VPDB $)$ to lower values $\left(\delta^{13} \mathrm{C} \sim 0 \%\right.$, $\delta^{18} \mathrm{O} \sim-6 \%$ ) in a $\sim 40 \mathrm{~m}$ thick interval including Plattenkalk and suggest ageing of the bottom waters. The surrounding reefs are isotopically nearly invariant $\left(\delta^{13} \mathrm{C} \sim+2 \%\right.$, $\delta^{18} \mathrm{O}$ $\sim-2 \%$ VPDB $)$. An isotope anomaly $\left(\delta^{13} \mathrm{C}\right.$ of $>\sim-9 \%$ o is restricted to the basinal facies and is most pronounced in the biostrome facies. This indicates methanogenesis, which is documented in negative $\delta^{13} \mathrm{C}$ in dedolomite, calcite-cemented dolomite and calcite concretions and occurred probably mainly below seabed. The Konservat-Lagerstätte was probably deposited near an oxygen minimum zone in a water column with low productivity of organic material. Dolomite is in isotopic equilibrium with Plattenkalk and was probably deposited as protodolomite from chemically modified, aged seawater. ${ }^{87} \mathrm{Sr} /{ }^{86} \mathrm{Sr}$ ratios of bulk carbonate are often slightly radiogenic, probably due to random analytical sample contamination by clay minerals. Belemnite and some matrix ${ }^{87} \mathrm{Sr} /{ }^{86} \mathrm{Sr}$ is slightly lower than that of Kimmeridgian seawater, either caused by basin restriction or by fluids derived from the diagenesis of Oxfordian rocks below. An equivalent Upper Kimmeridgian depression $\sim 23 \mathrm{~km}$ distant and a somewhat younger Konservat-Lagerstätte in Poland show a $\delta^{13} \mathrm{C}$ isotope anomaly below the main fossil beds. Isotopic evidence for saline bottom waters, the current interpretation, is lacking. This study also shows that micritic carbonates can preserve their early diagenetic, marine $\delta^{18} \mathrm{O}$ signal, which is correlatable over tens of kilometres.
\end{abstract}

\section{PROBLEM DEFINITION AND PURPOSE OF THE PAPER}

Plattenkalk (platy limestone) occurs in nearly all periods since the Late Precambrian (see overview in Oost, de Boer, 1994). As Konservat-Lagerstätten (Seilacher et al., 1985) they are characterized by an excellent preservation of fossils, especially articulated vertebrates. This feature is due to a hostile environment at the seabed, where no animals could disturb the sediment and descended organisms. Most famous are the Plattenkalk around Solnhofen and Eichstätt (Germany, Bavaria, Southern Franconian Alb, Fig. 1). The typical macroscopic feature of Plattenkalk is the planar bedding, undisturbed by bioturbation, often expressed in millimetre to decimetre alternations of dense, micritic limestone separated by thin clay seams (Viohl, 2015a). Beside this

\footnotetext{
${ }^{1}$ Technische Universität Clausthal, Institut für Geologie und Paläontologie, Leibnizstr. 10, D-38678 Clausthal-Zellerfeld, Germany; wolfgang.blendinger@tu-clausthal.de.

${ }^{2}$ Naturkunde-Museum Bamberg, Fleischstraße 2, D-96047 Bamberg, Germany; matthias.maeuser@en.uni-bamberg.de.
} 


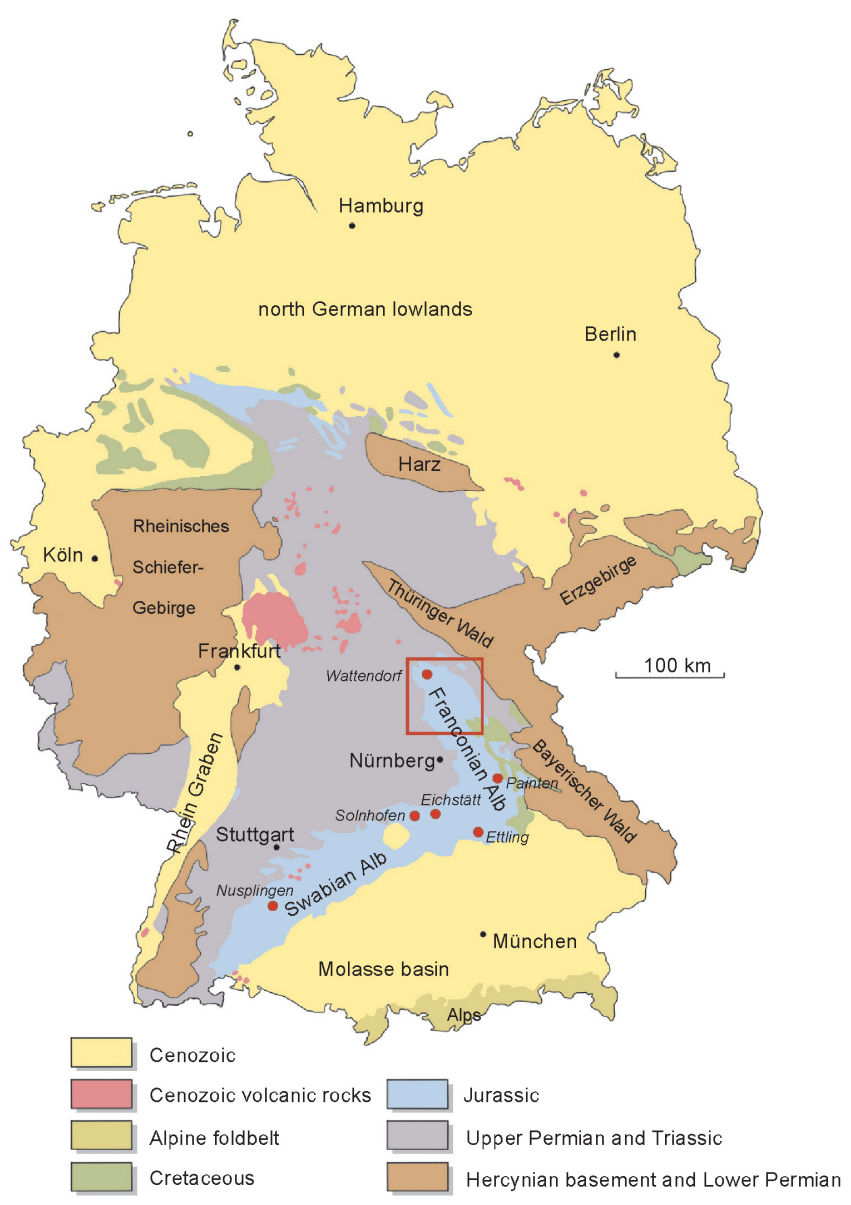

Fig. 1. Simplified geological map of Germany

The main occurrences of Plattenkalk are marked by red dots. Inset rectangle shows the location of $2 \mathrm{~A}$

typical pure "Solnhofen Limestone", there is a variety of different facies (Viohl, 2015b) ranging from mm-alternations of carbonate and claystone (the so-called Papierschiefer) to compact, decimetre beds of ultra-pure limestone (the so-called Flinz facies), but all have the plane parallel bedding and the nearly complete absence of evidence for benthic life in common. In Germany, Plattenkalk occurs from the Late Kimmeridgian to the Early Tithonian on a carbonate platform along the northern margin of the Tethys Ocean during a time frame of about 4 million years (Schweigert, 2015). The Wattendorf Plattenkalk discussed herein is the oldest known Plattenkalk of this special depositional environment, with an early Late Kimmeridgian age (Fürsich et al., 2007a, b; Mäuser, 2015). The term Plattenkalk as used in this paper also includes dolomitic facies unless otherwise specified.

Whereas the fossil content and stratigraphy of Plattenkalk are well known, a major unresolved question is the de- positional environment. Plattenkalk occurs in small isolated depressions, so-called Wannen (Fesefeldt, 1962; here called depression), surrounded by microbial-sponge reefs (Meyer, 2015; Viohl, 2015a-c). The isolation is thought to have produced salty brine pools and, locally, anoxic conditions on the bottom of the depressions caused by an increasingly arid climate. All studies so far have failed to provide more than circumstantial evidence for a hypersaline environment (cf. Arratia et al., 2015; Viohl, 2015c). In this paper, geochemical and compositional data from Plattenkalk and its stratigraphic frame in the Northern Franconian Alb are provided with the aim of contributing to a solution of the problems outlined above.

\section{REGIONAL SETTING AND PREVIOUS WORK}

The Jurassic of southern Germany consists of rocks deposited on a shallow, marine shelf. Most Plattenkalk occurrences are located on the southern Franconian Alb, and the Wattendorf area is the northernmost occurrence so far (Fig. 1). Lower and Middle Jurassic strata are dominated by claystone and sandstone with few calcareous intervals. In the Upper Jurassic, light coloured carbonates prevail. Rocks younger than Early Tithonian are missing in outcrop in southern Germany, and the fauna of the youngest rocks suggests a brackish influence and a Tithonian regression (Barthel, 1969). Relics of Cretaceous siliciclastic rocks occur locally (Fig. 2). The Upper Jurassic is differentiated into a "normal" facies of regularly bedded limestone-marl alternations (here called the basinal facies) and a massive facies (here called reef facies) dominated by microbial and micritic carbonate with varying amount of sponges and, only locally, corals. Below the Plattenkalk is a thick-bedded succession of dolomite and limestone called "tafelbankiger Dolomit" (Meyer, 1974; here called the biostrome facies).

For the Swabian Jurassic, Quenstedt (1856-1858) introduced subdivisions of the Lower (also called Lias), Middle (also called Dogger) and Upper Jurassic (also called Malm) rocks into six units each, labelled with the Greek letters alpha, beta, gamma, delta, epsilon and zeta $(\alpha, \beta, \gamma, \delta, \varepsilon$, and $\xi)$. This scheme was later adopted for the Franconian Jurassic. In this study, this stratigraphic subdivision and the term "Malm" are kept here. The new formation names introduced by Niebuhr and Pürner (2014), which are shown in Table 1 and Fig. 3, are less informative. According to Schweigert (2015) the usage of the old subdivisions is no longer permitted. However, the new formation names correspond to, with exceptions in the uppermost part of the Malm, the old subdivisions, albeit with a plethora of new names. New "type sections" expose only a few percent of the mapped thicknesses or are vertical, inaccessible cliffs of abandoned quarries in 

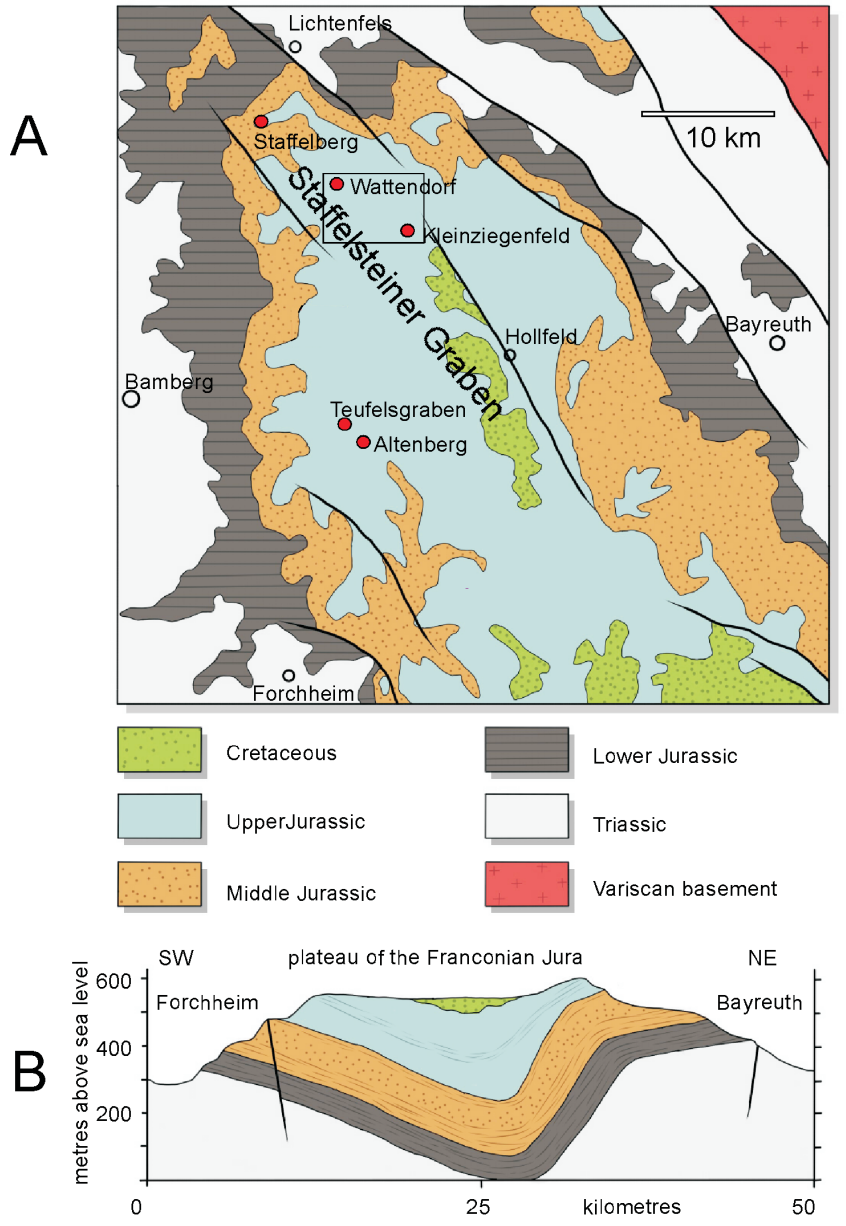

Fig. 2A. Simplified geological map of the northern Franconian Alb with the locations of the stratigraphic sections of Figs 4 and 7 , and the map of Fig. 3A (red rectangle); B. A cross-section of the northern Franconian Alb (modified after Meyer, Schmidt-Kaler, 1992) showing the tectonically depressed position of the Jurassic rocks many cases. For the understanding of the old subdivision only the basics of the Greek alphabet and the knowledge that $\alpha$ is the oldest and $\zeta$ the youngest are necessary. The studied rocks comprise essentially the Upper Kimmeridgian Malm $\delta$ (subdivided into $\delta 1-4$ ) and Malm $\varepsilon$, and parts of the Lower Kimmeridgian Malm $\gamma$.

The South German Jurassic, 500-900 m thick, is part of the flat-lying Mesozoic succession forming a triangular area framed by Hercynian basement rocks and the Alpine Molasse. The Franconian Alb is a gentle, slightly asymmetrical syncline (Fig. 2B) orientated NNW-SSE and 20-30 km wide. Its centre is structurally depressed by $\sim 200-300 \mathrm{~m}$. The Wattendorf area is located in the so-called Staffelsteiner Graben (Fig. 2A), a small graben structure with displacement of $\sim 25 \mathrm{~m}$, paralleling the regional NW-SE strike. As a result of the tectonic sag, the youngest Upper Jurassic rocks on the northern Franconian Alb are preserved in the Staffelsteiner Graben. The difference in elevation of the biostrome facies between the Staffelberg and Kleinziegenfeld, $\sim 15 \mathrm{~km}$ apart, is $\sim 100 \mathrm{~m}$ and indicates a structural SE dip of the graben axis of $<1^{\circ}$. The Altenberg is part of a small depression outside the graben and developed as a depression similar in size and age to the Wattendorf area. It was encircled by prograding reefs in the Kimmeridgian (Meyer, 1979) and was certainly isolated from the Wattendorf depression when Plattenkalk was deposited. Staffelberg and Kleinziegenfeld are located in different depressions. The stratigraphy, microfacies and fossils of the Wattendorf Plattenkalk are well documented (Fürsich et al., 2007a, b; Scharfenberg, 2011; Mäuser, 2015). The Wattendorf Plattenkalk differs from most other occurrences on the Franconian Alb in its stratigraphic position and the abundance of carbonate debris. Whereas the Plattenkalk of the southern Franconian Alb normally occurs above a few tens of metres of bedded, white micritic limestone overlying the biostrome facies, at Wattendorf it occurs directly above the biostrome facies. It is no surprise, therefore, that Wattendorf preserves the oldest Plattenkalk on the Franconian Alb. Limited geochemical

Table 1

Stratigraphic units of the study area with the scheme proposed in Niebuhr, Pürner (2014; grey; the term "subformation" is used as in the paper by Niebuhr, Pürner, 2014) and the old subdivision using greek letters for 6 units. For reasons of simplicity, the old subdivision is used here

\begin{tabular}{|c|c|c|c|c|c|c|c|c|}
\hline & & & & Old subdivision & Formation & \multicolumn{2}{|c|}{ Formation (basin facies) } & Subformation (Member) \\
\hline \multirow{6}{*}{ 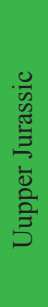 } & \multirow{6}{*}{ 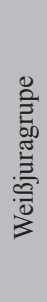 } & \multirow{6}{*}{ 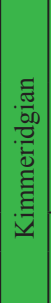 } & \multirow{4}{*}{$\begin{array}{l}\dot{0} \\
\stackrel{0}{\vec{D}}\end{array}$} & Malm $\varepsilon$ & \multirow{6}{*}{$\begin{array}{l}\text { Frankenalb } \\
\text { Formation } \\
\text { (reef limestone } \\
\text { and dolomite) }\end{array}$} & \multirow{3}{*}{$\begin{array}{l}\text { Pottenstein Formation } \\
\text { (biostrome facies) }\end{array}$} & $\begin{array}{c}\text { Torleite Formation } \\
\text { (white, micritic limestone) }\end{array}$ & \multirow{2}{*}{$\begin{array}{l}\text { Wattendorf Subformation } \\
\text { (Plattenkalk plus } \\
\text { white basinal limestone) }\end{array}$} \\
\hline & & & & $\mathrm{Malm} \delta 3+4$ & & & Treuchtlingen Formation & \\
\hline & & & & 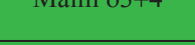 & & & (thick-bedded limestone) & \\
\hline & & & & Malm $\delta 1+2$ & & \multirow{3}{*}{\multicolumn{2}{|c|}{$\begin{array}{l}\text { Ebermannstadt Formation } \\
\text { e and argillaceous basinal limestone) }\end{array}$}} & ?Teuchatz Subformation \\
\hline & & & \multirow{2}{*}{$\underset{1}{\stackrel{5}{0}}$} & Malm $\gamma 2$ & & & & \\
\hline & & & & Malm $\gamma 1$ & & & & Burgstall Subformation \\
\hline
\end{tabular}




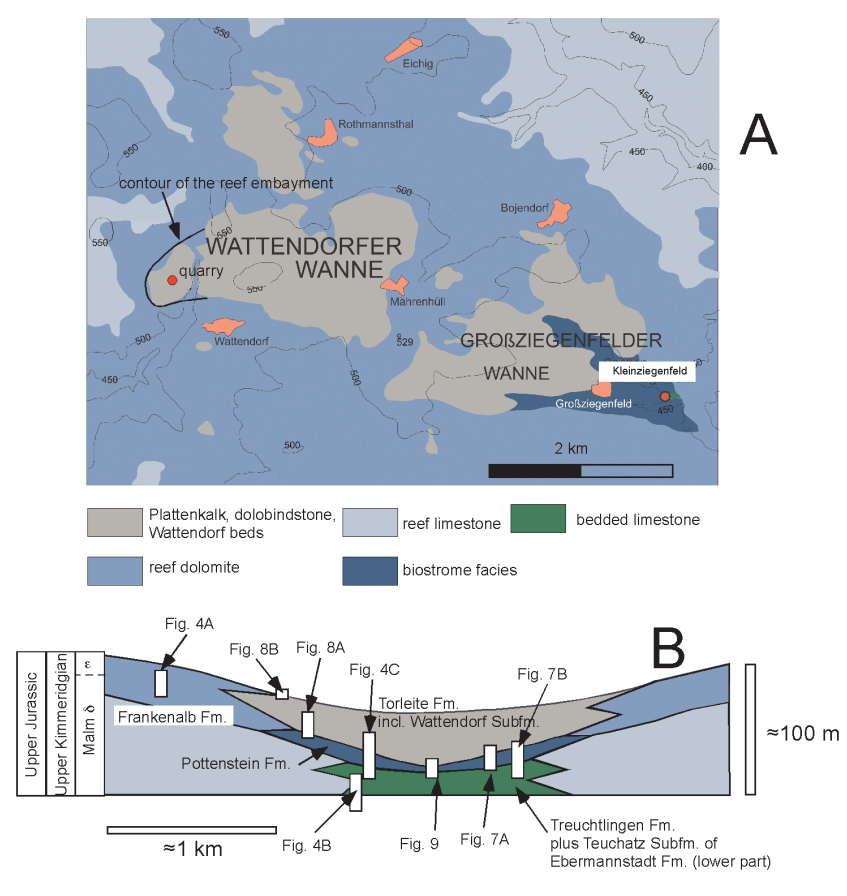

Fig. 3A. Geological map of the Wattendorf area (for location see Fig. 2A, modified from Hegenberger, Schirmer, 1976), and location of the quarry. The Kleinziegenfeld section (red circle) is the only location in the map area where bedded limestone is exposed below the biostrome facies (Fig. 7B). Contour interval is 50 metres above sea-level. The outline of the depression is only well defined in the quarry area, and it is likely that the depressions of Wattendorf and Kleinziegenfeld were separate depression during deposition of Plattenkalk; B. Schematic cross-section of an Upper Jurassic depression, showing the conventional subdivision of the Malm, and the new formation names (Niebuhr, Pürner, 2014), which are not used in the present study.

The vertical rectangles show the stratigraphic and palaeogeographic positions of the isotope profiles of Figs 4, 7, 8 and 9. Colours as in (A)

data are available from the Franconian Jurassic. Bausch and Hoefs (1972) measured stable isotopes of dolomite and limestone. A better geochemical database exists for the Upper Jurassic of the Swabian Alb and the subsurface of the Molasse basin (cf. Fig. 1) (Koch, Schorr, 1986; Liedmann, 1992; Reinhold, 1998; Ruf et al., 2003; Herrmann et al., 2018, and Mraz et al., 2019). Ruf et al. (2003) showed that not only $\delta^{13} \mathrm{C}$ but even $\delta^{18} \mathrm{O}$ is correlatable over large distances, and suggested that diagenetic modifications of the stable isotope signal were minimal. Munnecke et al. (2008) studied rare earth elements from the Plattenkalk of the Solnhofen area. The porosity of South German Jurassic limestone is typically on the order of $1-10 \%$, and the low to very low permeabilities range from $<1$ microdarcy to a few millidarcies (Homuth, 2014). The only other Konservat-Lagerstätte for which systematically sampled stable isotope data are available is the Owadów-Brzezinki quarry in Poland (Wierzbowski et al., 2016). It is slightly younger than Wat- tendorf (Middle Volgian corresponding approximately to the latest Early Tithonian) and also occurs in a slightly different stratigraphic framework, a shallow shelf setting with local occurrences of evaporites.

\section{METHODS}

Five stratigraphic sections and four drill cores were sampled for isotope and phase analysis (specimens of several $\mathrm{cm}^{3}$ in size), with a sample increment of $1 \mathrm{~m}$ in most drill cores. The Altenberg was sampled in order to obtain data for a comparison with Wattendorf. Sampling had the aim of detecting possible isotope trends.

\section{X-RAY DIFFRACTION (XRD) AND X-RAY FLUORESCENCE (XRF)}

For the purpose of better quantifying the mineralogical database, X-ray diffractometry was carried out on 61 samples For the X-ray phase analyses a PhilipsPW1710 with Co or $\mathrm{Cu} \mathrm{K \alpha}$-radiation, respectively $(1 \mathrm{~nm}$; Ni filter, under $30 \mathrm{kV}$ and $30 \mathrm{~mA}$ with a step increment of $0.004^{\circ}$ ) was used. Approximately $1 \mathrm{~cm}^{3}$ of each sample were powdered to analytical fineness in a vibratory disc mill using a tungsten carbide grinding set. For the semi-quantitative determination of the content of different carbonates and the exact location of the dolomite and calcite $\mathrm{d}(104)$ peak in the samples, $\mathrm{CaF}_{2}$ was added as internal standard in a ratio of $1: 5$. In order to achieve randomly oriented aggregates, which allow comparison of the relative intensities of a series of peaks, the powder was carefully scraped into the cavity of the aluminium holder and only gently pressed with a glass slide to counteract the tendency of particles to lie parallel to the glass surface. The evaluation was performed using the software program Xpert High Score (by Panalytical). Calculation of dolomite stoichiometry was performed with the equations of Kaczmarek, Sibley (2011). Three hand specimens were slabbed, polished and analysed with the portable X-ray fluorescence analyser Niton XL3t (by Analyticon) for major elements in vertical profiles. A total of 19 measurements was carried out.

\section{STABLE ISOTOPE ANALYSIS}

Six hundred and five samples were analysed for stable isotopes of oxygen and carbon at the Geozentrum Nordbayern in Erlangen. Sample material $(0.5-1.0 \mathrm{~g})$ was drilled with a $1 \mathrm{~mm}$ bit from fractured rock samples and slabbed surfaces respectively, and reacted with $100 \%$ phosphoric 
acid at $70^{\circ} \mathrm{C}$ using a Gasbench II connected to a ThermoFisher Delta V Plus mass spectrometer. Reproducibility and accuracy was monitored by replicate analysis of laboratory standards calibrated by assigning $\delta^{13} \mathrm{C}$ values of $+1.95 \%$ to NBS19 and $-47.3 \%$ to IAEA-CO9 and $\delta^{18} \mathrm{O}$ values of $-2.20 \%$ to NBS19 and $-23.2 \%$ to NBS18. Reproducibility for $\delta^{13} \mathrm{C}$ and $\delta^{18} \mathrm{O}$ was $\sim \pm 0.05 \%$. The $\delta^{18} \mathrm{O}$ data were reported for calcite relative to the PDB standard in the usual delta notation. Phosphoric acid fractionation of dolomitic samples was not corrected. Uncertainty of the exact fractionation factor has not improved since Land (1980).

\section{Sr ISOTOPES AND CONCENTRATION}

Fifty-eight carbonate samples were analysed for ${ }^{87} \mathrm{Sr} /{ }^{86} \mathrm{Sr}$ ratios at the Institute for Material Analysis and Science, Göttingen. Prior to digestion, all samples were spiked with a tracer solution ( $\mathrm{Sr} 4-\mathrm{AD})$ and dissolved in Teflon flasks by various steps of addition and evaporation of $2.5 \mathrm{~N} \mathrm{HCl}$ until complete dissolution. The column procedure using Micro Bio-Spin Columns (Bio-Rad) with Sr-Resin-B (Triskem) was applied to separate $\mathrm{Sr}$. The isotope measurements were done with a ThermoFinnigan TIMS Triton TI. Instrumental mass bias was corrected with ${ }^{88} \mathrm{Sr} /{ }^{86} \mathrm{Sr}$ of 0.1194 using exponential law. Concentrations were calculated using ID-TIMS technique. Within this study, the average value for NBS 987 $(n=9)$ is $0.71027 \pm 7$, which is consistent with the long-term average ${ }^{87} \mathrm{Sr} /{ }^{86} \mathrm{Sr}$ value of the laboratory $(0.71027 \pm 5$, $\mathrm{n}=466$ ). The difference between the standard used here and the internationally recommended standard NBS SRM 987 (e.g., McArthur, 1994) is 0.000022 and negligible for the purpose of this study. Additionally, $\mathrm{Sr}$ concentrations of hand specimens were measured by XRF at 19 sample points of 2 slabbed and polished hand specimens. The ${ }^{87} \mathrm{Sr} /{ }^{86} \mathrm{Sr}$ ratios of tooth apatite were measured according to the method described in Mudroch (2001).

\section{RESULTS BEDDED LIMESTONE ("BANKKALK")}

Bedded limestone is a succession of beige, light grey or greenish-grey, micritic, tight limestone in decimetre to metre-thick beds. The bedding planes are uneven and are caused by laterally continuous, flaser bedded marly layers. The fossil content includes ammonoids, sponges and crinoid ossicles but other other macro-fossils were not found. The limestone is locally marly, mainly in the lower part of the Malm $\delta$ and in the Malm $\gamma$ of the Teufelsgraben and Altenberg sections (Fig. 4). Compact limestone intervals serve as lithostratigraphic subdivision of the Kimmeridgian $(\gamma 1-2$, $\delta 1-4)$ on the northern Franconian Alb (Fig. 4). The Wattendorf beds, mapped as Malm $\varepsilon$, are the youngest unit and consist of a monotonous succession of white, micritic and mostly tight limestones in decimetre-thick beds. In the quarry about $25 \mathrm{~m}$ of this unit are exposed (Mäuser, 2015). Hegenberger and Schirmer (1967) mapped a maximum thickness of $\sim 70 \mathrm{~m}$. Corals, brachiopods and diceratid bivalves are concentrated in reef debris layers. Decimetre-voids elongated parallel to the bedding occur preferably in a few intervals. The voids are mostly empty, but occasionally consist of white chert with concentric laminae, compact grey chert, and red clay. In the quarry, the topographically highest Wattendorf beds are dolomitic and grade up-dip into a massive, vaguely clinostratified dolomite indistinguishable from the dolomitic reef facies. At the Altenberg, the Wattendorf beds are not exposed but were sampled from scree. Bedded limestone (and reef limestone and dolomite) always shows a contamination with detrital clay, reflected in an acid insoluble residue of $<15 \%$, mainly illite and kaolinite and is, therefore, locally marly limestone (Meyer, 1979). The Wattendorf beds are an exception and contain $<<5 \%$ insoluble residue, which is the reason for quarrying this ultra-pure limestone (cf. Mäuser, 2015).

\section{REEF LIMESTONE}

Kimmeridgian reef limestone is $\sim 120$-m thick largely comprising the Malm $\delta$ and part of the Malm $\gamma$ (Hegenberger, Schirmer, 1967). It is macroscopically a grey micrite forming thick $(>1-2 \mathrm{~m}$ ) beds with, in general, only few macrofossils such as brachiopods, crinoid ossicles and sponges. The upper part shows metre thick intervals of light beige limestone. Macroporosity is restricted to a few intervals and estimated to $10-15 \%$. Calcified siliceous sponges, centimetres to a decimetre in diameter, are very abundant in some intervals, their platy geometry is either subhorizontal or inclined at $20-30^{\circ}$ in a drill core. Sponges do not form a framework but are always floating in a micritic matrix. Decimetre-thick, dark grey intervals with flaser lamination are occasionally intercalated. In outcrop, the reef limestone is slightly more greenish than in the cores and shows a faint apparent horizontal stratification and clinostratification, which can be measured only at very few localities.

\section{REEF DOLOMITE}

In Wattendorf, only a few metres of reef dolomite are preserved above the reef limestone. The Altenberg preserves about $30 \mathrm{~m}$ (Fig. 4). The reef dolomite traces the outline of 

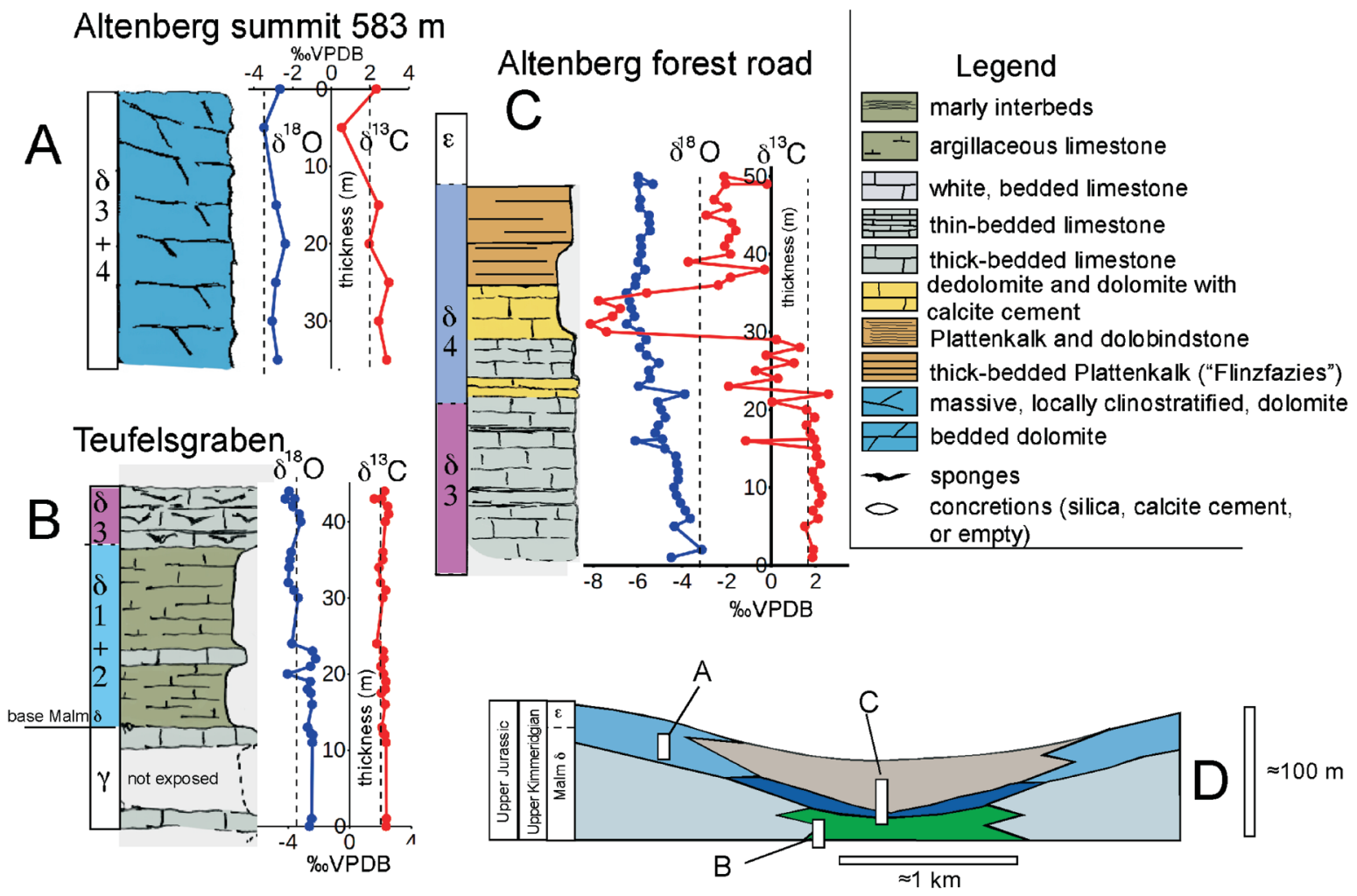

Fig. 4. Lithology and isotope profile of the Teufelsgraben and Altenberg sections and subdivision of the Malm $\delta$ (modified from Meyer, 1979; for location, see Fig. 2A)

The reef dolomite section (A) is from the main summit of the Altenberg, the Teufelsgraben section (B) is the Teufelsgraben-NW section of Meyer (1979), the Altenberg SE section (C) is the forest road section in Meyer (1979, p. 60). D. The position of the sections in the depression. Inset is the legend for all lithology columns (Figs 4, 7-9). The stippled vertical lines in the stable isotope profile are for orientation at $-3,5$ and $+2 \%$. Scales are in the isotope logs

the small embayment at the western edge of the Wattendorf depression, where the Plattenkalk occurs (Fig. 3A; Mäuser, 2015). Reef dolomite can show a distinct clinostratification with angles of $<20^{\circ}$ (Fig. 5A) but also indistinct subhorizontal bedding at the metre-scale. The lateral and vertical contacts with reef limestone and dolobindstone, respectively, are abrupt (Fig. 5B). Reef dolomite is a sucrosic, white to dark grey rock with occasional diceratid bivalves and brachiopods. Occasionally, the dolomite shows a low intercrystalline porosity, but is otherwise a tight and hard rock. Sucrosic dolomite interbeds occur in the Plattenkalk and can

Fig. 5. Reef dolomite - Plattenkalk relationships in the Wattendorf quarry

A. The lateral transition for the Plattenkalk, here mainly composed of dololaminite and sucrosic dolomite, into vaguely clinostratified reef dolomite. Reef flanks are always dolomitic; B. A layer of sucrosic dolomite within the lower part of the Plattenkalk mainly consisting of dolobindstone. The dolomite is locally a dolomite sand and contains calcite concretions, similar to the dololaminite in the upper part of the outcrop. The downward bulge and the disrupted Plattenkalk in the left part is possibly the result of gravity sliding of the dolomite

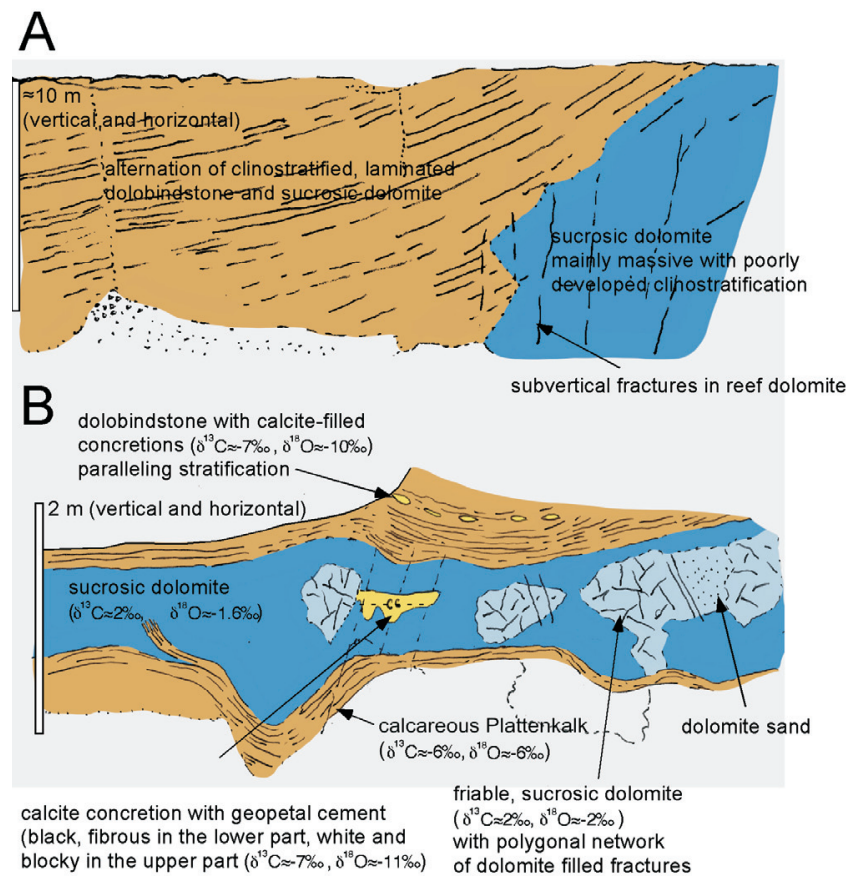


show considerable thickness changes, associated with disrupted and deformed Plattenkalk below (Fig. 5B). Dolomite microfacies shows a relict of a clotted-peloidal fabric typical for microbial boundstone. The idiomorphic to hypidiomor-
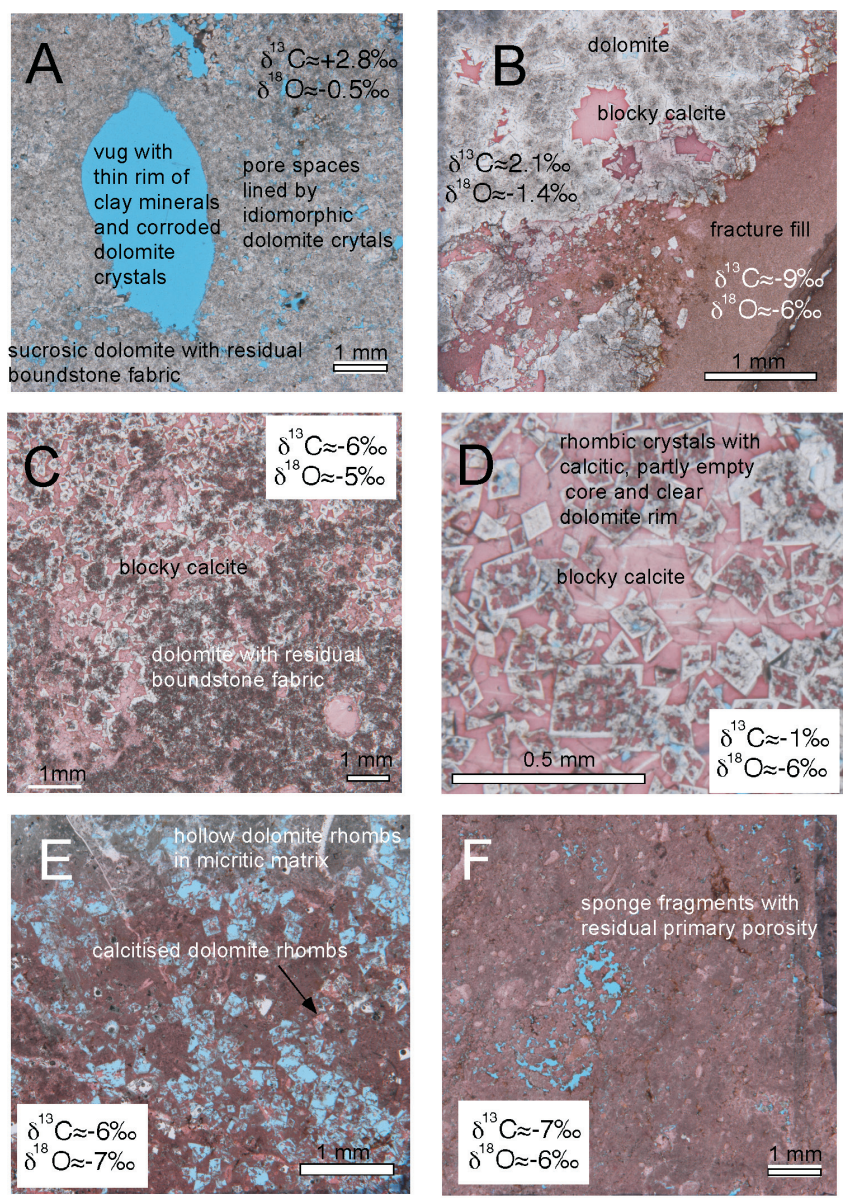

Fig. 6. Thin section micrographs of dolomite and facies with very negative $\delta^{13} \mathrm{C}$. All thin-sections stained with Alizarin red-S and impregnated with blue dye epoxy to show porosity

A. A sucrosic dolomite with a relict clotted-peloidal fabric consisting of crystals showing a turbid (grey) core and a clear rim. Large subround vugs are lined with thin clay seams and have corroded dolomite crystals, other intercrystalline pore spaces are bordered by idiomorphic dolomite crystals without evidence for leaching. For location see Fig. 7B; B. The contact between a sucrosic dolomite and (yellow) calcitic micrite filling of a fracture of the Wattendorf quarry. The boundary between the micrite and dolomite matrix shows corroded dolomite crystals, pore spaces in dolomite are filled with clear calcite; C. A sucrosic dolomite with intercrystalline pore spaces partly filled with clear, sparry calcite. The negative $\delta^{13} \mathrm{C}$ probably is a mix value of positive dolomite and negative calcite, mixed during sample drilling. For location see Fig. 9; D. Rhombs with a clear dolomite rim and partly leached cores, in which the clotted-peloidal fabric has been preserved, and clear blocky calcite filling the residual pore spaces. For location see Fig. 7A; E. A dedolomite with hollow dolomite rhombs and calcitized dolomite crystals in a stromatolitic boundstone; $\boldsymbol{F}$. A peloidal micrite/boundstone with partly shell debris and porous sponge fragments. For location see Fig. 9 phic dolomite crystals are $<0.5 \mathrm{~mm}$ in size and show turbid cores and a clear rim, typical for most dolomites (Purser et al., 1994). Most millimetre-sized vugs have rims of idiomorphic dolomite crystals, but centimetre-sized, round vugs (Fig. 6A) show thin tapestries of clay minerals lining corroded dolomite crystals. Centimetre-wide subvertical fractures in reef dolomite are filled with light beige, unlaminated lime mudstone and are several decimetres long (Fig. 6B).

\section{BIOSTROME FACIES}

The biostrome facies forms the foundation of all Plattenkalk occurrences in Southern Germany. For this study, these carbonates were logged at the Staffelberg, Kleinziegenfeld (Fig. 7), the Altenberg (Fig. 4), a cored borehole in the Wattendorf quarry (Fig. 8) and a cored borehole in the central part of the Wattendorf depression (Fig. 9). In contrast
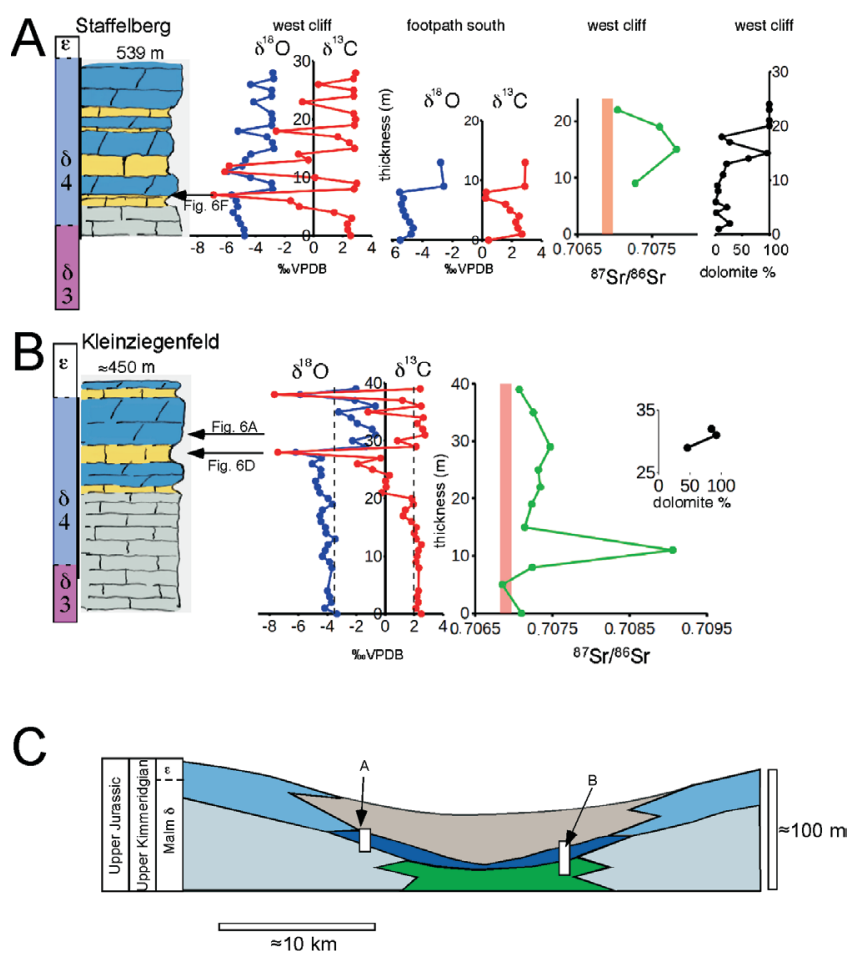

Fig. 7A, B. Stratigraphic sections, isotope logs and XRD data from the Staffelberg and Kleinziegenfeld (for location, see Figs 2A, 3A)

The biostrome facies of both sections shows strong negative $\delta^{13} \mathrm{C}$ excursions. These are correlatable between the two Staffelberg profiles, west cliff and the partial section footpath south are $\sim 300 \mathrm{~m}$ apart. The stippled vertical lines in the stable isotope logs are for orientation at -3.5 and $+2 \%$. Red bar in the ${ }^{87} \mathrm{Sr} /{ }^{86} \mathrm{Sr}$ diagram delineates Kimmeridgian seawater (Wierzbowski et al., 2017). The XRD data indicate that dolomite always shows positive $\delta^{13} \mathrm{C}$ values; C. The schematic position of the sections in the depression. Scales are in the isotope logs 


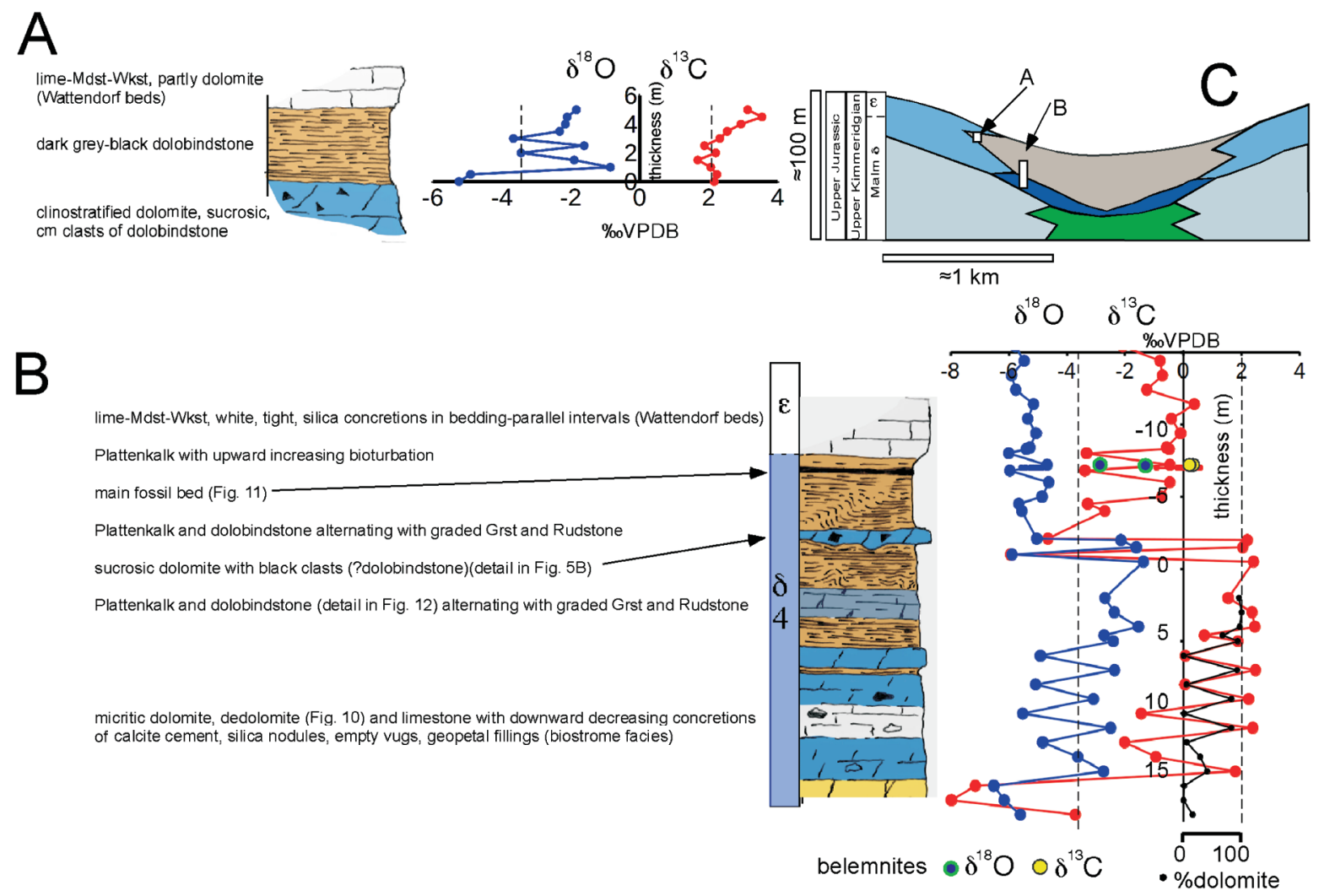

Fig. 8. Lithology and isotope profiles of the Plattenkalk in the Wattendorf quarry

A. A section from the upper part of the reef flank covered by entirely dolomitic Plattenkalk (dolobindstone). Section B is $\sim 40 \mathrm{~m}$ lower than section A. About $50 \%$ of the Plattenkalk are presently below the surface (reference depth $=0 \mathrm{~m}$ ). The Plattenkalk is underlain by a succession of porous dedolomite, tight dolomite and limestone (biostrome facies). XRD measurements (scale at the lower end of the isotope diagram, black circles and lines) document that dolomite always has positive $\delta^{13} \mathrm{C}$ and heavier $\delta^{18} 0$ than limestone. The stippled vertical lines in the stable isotope logs are for orientation at -3.5 and $+2 \%$; C. The approximate position of $(A)$ and $(B)$ in the depression. Scales are in the isotope logs

to the reef facies, it is a distinctly stratified succession, $<30 \mathrm{~m}$ thick, of interbedded dolomite, dedolomite and micritic limestone in decimetre to metre beds. The sucrosic dolomite intervals are similar to the reef dolomite and preserve a stromatolitic fabric including dedolomite (Fig. 10). Sponges occur occasionally. Centimetre-sized voids with irregular geometry and smooth outlines are common and decrease downward in abundance in the drill core of Wattendorf quarry. These are empty in most cases, but occasionally show geopetal fills of white silica powder or blocky calcite containing angular fragments of the host rock, overlain by beige calcite silt. A peculiarity of the biostrome facies is the occurrence of calcite cement in sucrosic dolomite and dedolomite (Fig. 6C, D). The clear, blocky calcite partly fills mm-sized pore spaces between idiomorphic dolomite crystals (Fig. 6C). Dedolomite shows rhombs with a calcitic core, in which the residual boundstone fabric is preserved, surrounded by a clear dolomite rim. The pore spaces between the rhombic crystals is largely filled with clear blocky calcite (Fig. 6D), which shows plane, uncorroded boundaries with pore spaces. Boundstone fabric with cloudy zones of darker and lighter colour and an estimated $15-20 \%$ porosity is typical (Fig. 10; see also Mäuser et al., 2002). Micritic facies show calcitised dolomite rhombs and partly to totally empty rhombs (Fig. 6E), but are often similar to the limestone of the bedded facies (Fig. 6F).

\section{PLATTENKALK}

The Wattendorf Plattenkalk can be subdivided into a dolomitic and a calcareous facies (Mäuser, 2015). Plattenkalk contains abundant well preserved vertebrate fossils, typical for a Konservat-Lagerstätte. particularly in a $20 \mathrm{~cm}$ thick bed in the upper part of the succession (Fig. 8B, 11). In the quarry, the upper $7.5 \mathrm{~m}$ are exposed (Mäuser, 2015), and 
A
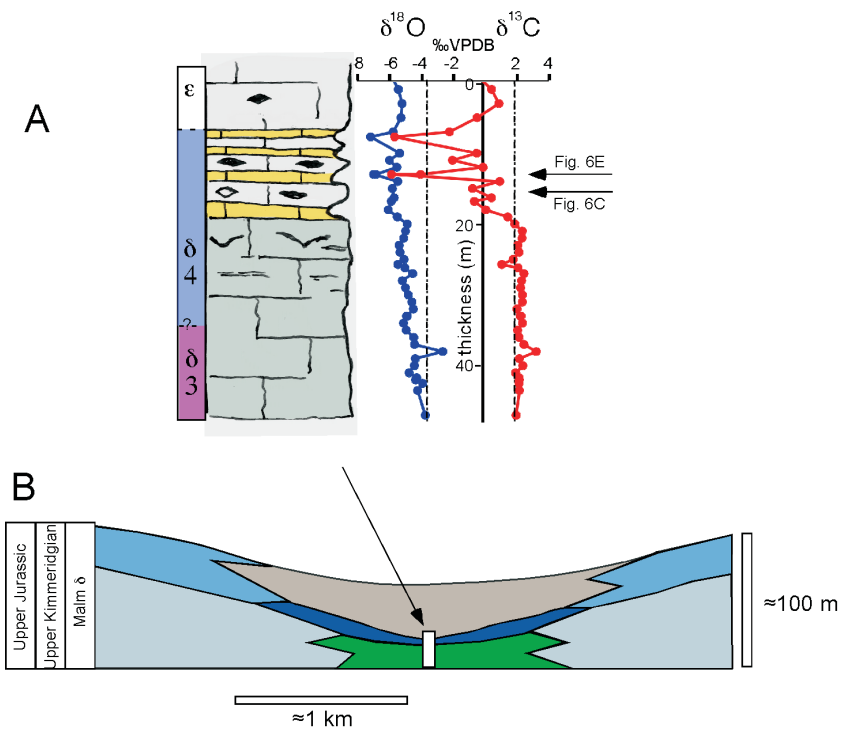

Fig. 9A. Lithology column and isotopes of part of a well in the centre of the Wattendorf depression (cf. Fig. 3A). The well shows only very thin porous dedolomite and dolomite with calcite cement intervals (biostrome facies) separating the Wattendorf beds from the underlying grey basinal limestone. Plattenkalk is lacking in this core. The stippled vertical lines in the stable isotope $\log$ are for orientation at -3.5 and $+2 \%$ o. Scale is in the isotope log. B. The schematic position of the section of $A$

a drill core below the quarry sole shows another $7 \mathrm{~m}$ of this succession (Fig. 8). The Wattendorf Plattenkalk is therefore 14-15 m thick. The dolomitic facies is an alternation of millimetre- to $\mathrm{cm}$-thick light beige and grey, micritic, laminated layers with a fabric reminiscent of layered stromatolites and called dolobindstone in Mäuser (2015). This alternates with normally graded beds (Fig. 12), which are calcareous and contain fossil debris of brachiopods, bivalves, echinoderms and corals. The fabric of these beds is rudstone to fine grainstone, and the cement is a transparent, blocky calcite (Scharfenberg, 2011). The exact percentage of detrital layers was not quantified, but it is estimated that Plattenkalk makes up $\sim 50 \%$ of the $15 \mathrm{~m}$ thick succession. Locally, slump structures (Mäuser, 2015) and low angle $\left(10-15^{\circ}\right)$ reverse faults are seen, with drag folds documenting a horizontal displacement of a few metres towards the centre of the depression. Millimetre-wide, dolomite-filled fractures are restricted to the intervals with inclined stratification (Fig. 11B). The calcareous Plattenkalk shows a laminated fabric similar to that of the dolobindstone. It shows very thin $(<<1 \mathrm{~mm})$ claystone layers which allow the rock to be split parallel to the bedding. Detrital layers are common and similar in composition and thickness to those of the dolobindstone. Organic matter, qualitatively recognized during rock slabbing by the odour of kerosene, is limited to the dolomitic intervals $(<\sim 0.5 \%$ Total Organic Carbon (TOC), Kreiensiek, 2019), whereas

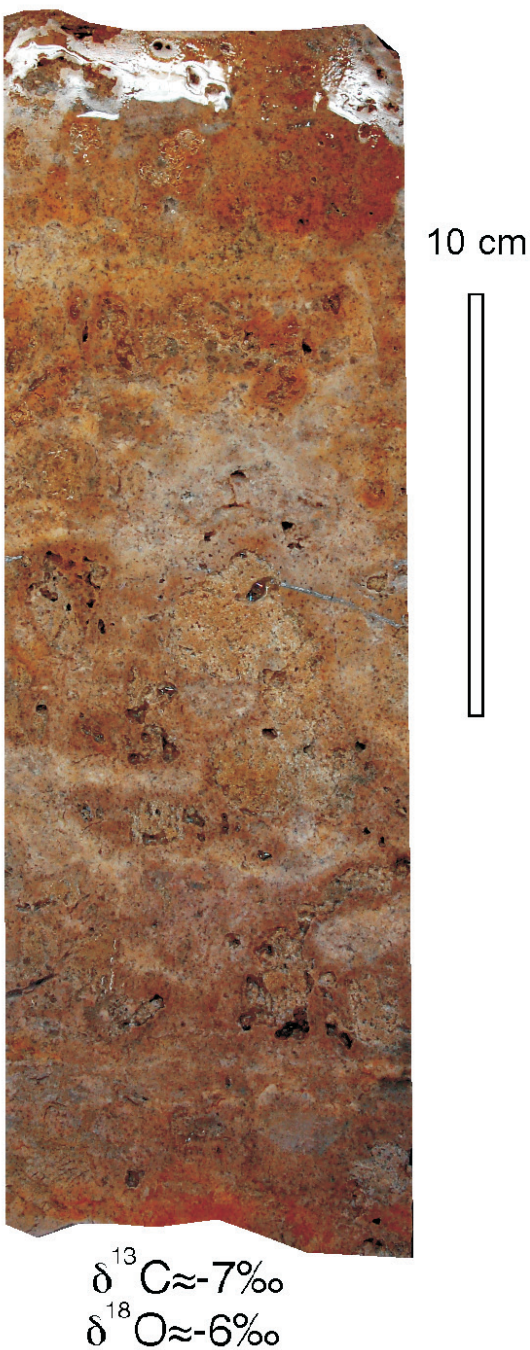

Fig. 10. Polished hand specimen of a dedolomite of the biostrome facies

The fabric suggests a stromatolitic boundstone composed of light and dark coloured carbonate, light coloured parts in the upper half are similar to cauliflower stromatolites. The estimated porosity is $20-30 \%$, open vugs are the darkest areas on the polished cross section

the Plattenkalk is practically free of TOC. The Plattenkalk is an extremely pure limestone, but the thin layers of clay minerals prevent a commercial use of this facies. Diagenetic products include chert and calcite nodules which are concentrated in some horizons (Fürsich et al., 2007a, b; Mäuser, 2015). Calcitic concretions locally form a replacement of the originally laminated intervals, by different types of coarse fibrous calcite crystals (Fig. 5B, 12). One is a dark, fibrous calcite replacing the graded intervals, and a lighter coloured calcite replacing the micritic part. The chert nodules are similar in size and geometry and consist of white, unconsolidated silica which probably also originally filled 


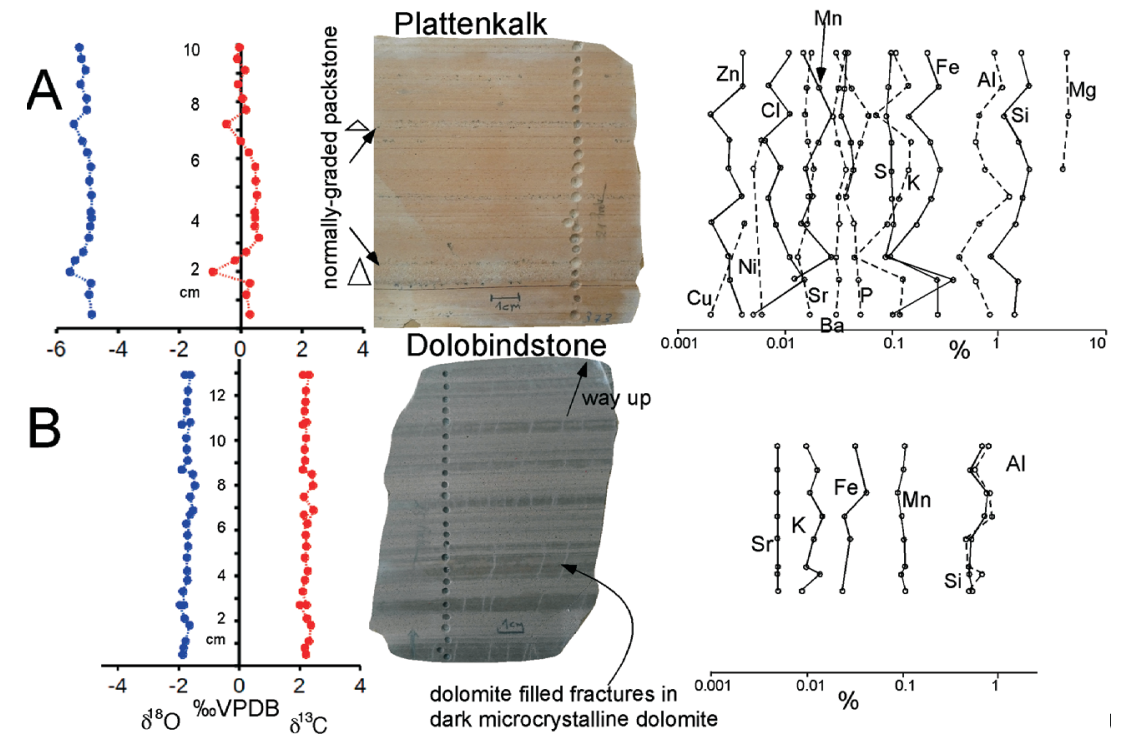

Fig. 11. Polished hand specimens of Plattenkalk and dolobindstone and their measured parameters

A. The Plattenkalk sample represents the main fossil bed and contains normally graded grainstone intervals (triangle symbols) with negative stable isotope excursions; B. The dolobindstone sample from the inclined beds on the reef flank (way-up marked by the arrow) shows a very consistent stable isotope composition. Fractures oblique to bedding occur in intervals interbedded with unfractured dolomite and suggest small slide structures and/or differential compaction. The isotopic differences between limestone and dolomite suggest precipitation from similar fluids. The major element analysis showed no conspicuous anomalies. Co-varying Si, Al, $\mathrm{K}$ and Fe indicate that these elements are from clay minerals. Scales are in the isotope logs

the now empty vugs. The host rock is undisturbed by the nodule geometry. Dolobindstone and reef dolomite interfinger (Fig. 5A). The interfingering is a gradual, isopachous up-dip facies change from dolobindstone into sucrosic reef dolomite.

At the Altenberg $\sim 10 \mathrm{~m}$ of a light beige Plattenkalk are exposed, which show planar bedding of decimetre-thick intervals similar to the so-called Dickflinz-Fazies of the southern Franconian Alb. This facies lacks the millimetre lamination of the Wattendorf counterpart, but also the marl interbeds typical of the Dickflinz-Fazies. The succession is only exposed in a narrow vertical cliff, and no fossils were found. All Plattenkalk varieties are characterized by an extremely low content of insoluble residue mainly consisting of illite/montmorillonite and kaolinite (1-3\%; Viohl, $2015 b)$, similar to the Wattendorf beds. The clay mineralogy of the studied Plattenkalk was not quantified, but the presence of clay is documented in the co-varying $\mathrm{Al}, \mathrm{Fe}$ and $\mathrm{Si}$ contents (Fig. 11A).

\section{Fig. 12. Polished cross section of a dolobindstone from the Wattendorf quarry}

The fabric shows alternating millimetric layers of laminated, light coloured dolomicrite, locally in the upper part with small cushions similar to domal stromatolites, and normally graded beds, marked by the triangles at the right, consisting of reef debris. The calcite nodule in the lower part is a replacement of a detrital limestone by calcite crystals

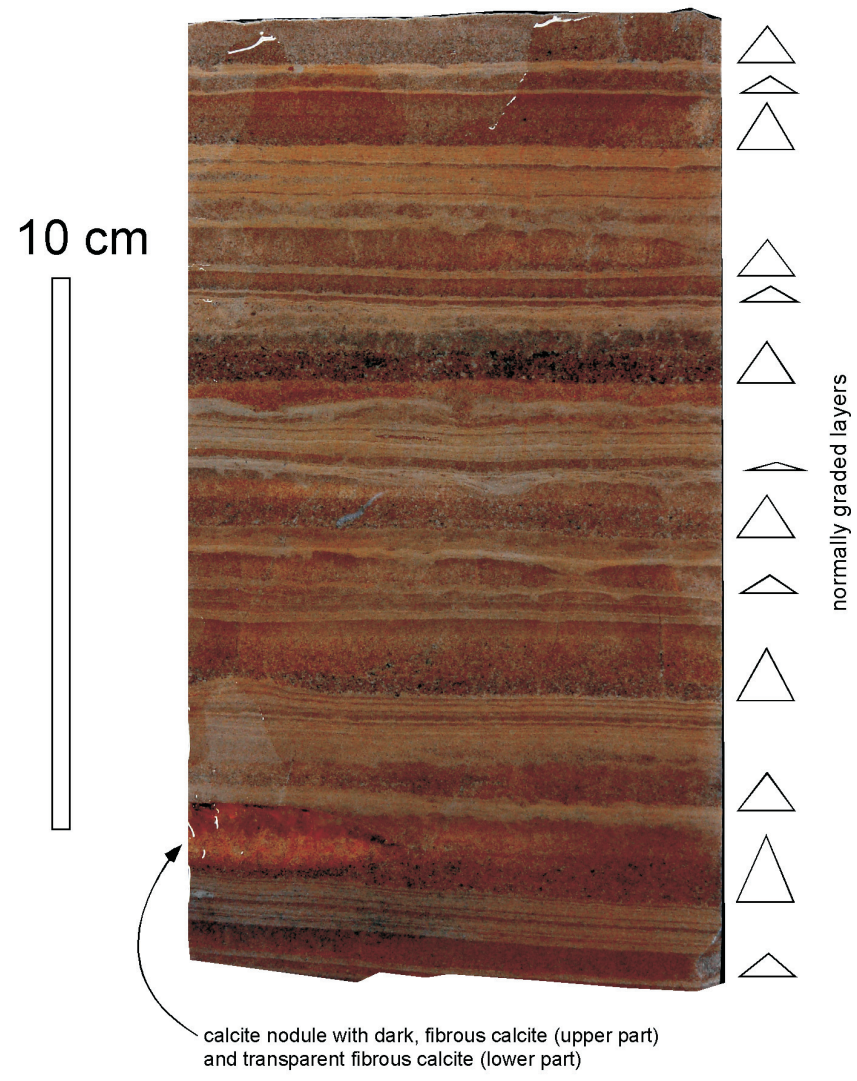




\section{XRD AND XRF ANALYSIS}

The X-ray diffractograms (Fig. 13) show that the investigated rocks consist either of pure calcite (with amounts of $\mathrm{Mg}$ below detection limit), or pure dolomite, and mixtures of these. The peaks of the main reflection of dolomite show slight shifts of the $\AA$ values, which show that the $\mathrm{CaCO}_{3}$ content of dolomite ranges from $\sim 50$ to $57 \mathrm{Mol}_{0} \mathrm{CaCO}_{3}$ with a bimodal distribution (Fig. 13E). The X-ray fluorescence analysis of the two hand specimens from the Plattenkalk and the dolobindstone show that $\mathrm{Si}, \mathrm{Al}, \mathrm{K}$ and Fe clearly covary in the Plattenkalk and the dolobindstone, and the percentage of these elements is comparable (Fig. 11). Sr concentrations are $\sim 120 \mathrm{ppm}$ in the calcareous Plattenkalk, but much lower in the dolobindstone ( $\sim 50 \mathrm{ppm})$. The difference between limestone and dolomite is typical.

\section{STABLE ISOTOPES}

The stable isotopes range from $\sim+4$ to $-9 \%$ for $\delta^{13} \mathrm{C}$ and $\sim-1$ to $-11 \%$ for $\delta^{18} \mathrm{O}$ (Fig. 14). The resulting data
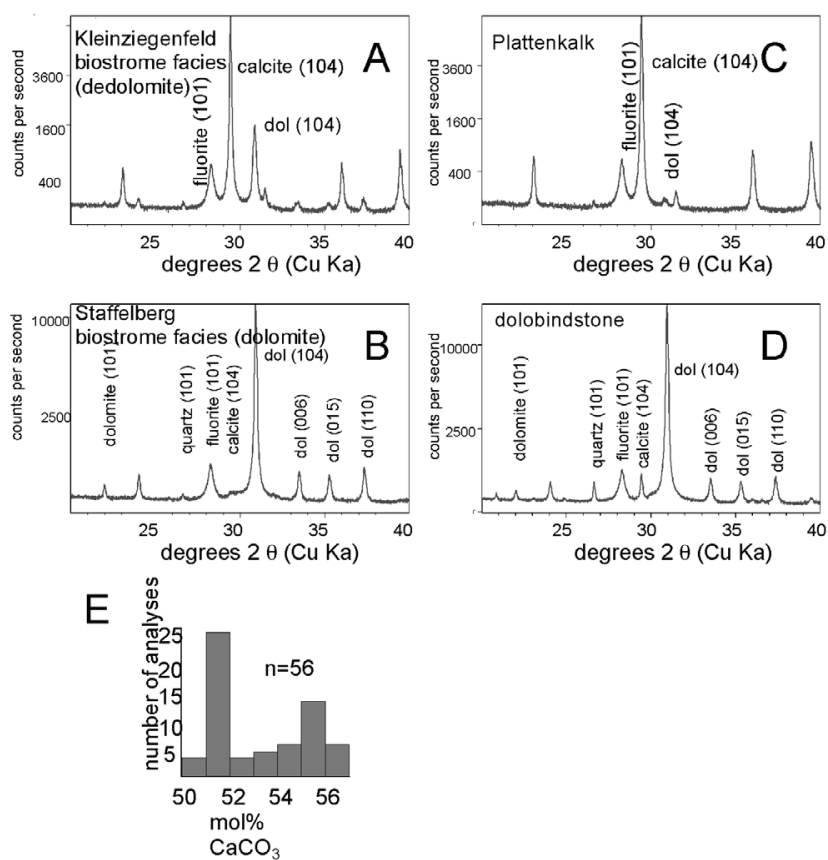

Fig. 13. X-ray diffractograms of the biostrome facies: (A. dedolomite; B. dolomite) and Plattenkalk (C: limestone; D: dolomite)

All reflections of calcite correspond to a Mg-free calcite, but the major (104) reflection of dolomite can show slight shifts related to the $\mathrm{Mol}_{0} \mathrm{CaCO}_{3}$. Fluorite peak is from the internal $\mathrm{CaF}_{2}$ reference. The histogram of the calculated dolomite stoichiometries (E) shows a bimodal distribution, similar to most dolomite (Searl, 1994) spread is $\sim 14 \%$ or $\delta^{13} \mathrm{C}$ and slightly smaller, $\sim 10 \%$, for $\delta^{18} \mathrm{O}$. The most positive values were measured in reef limestone and dolomite $(14 \mathrm{~B}, \mathrm{C})$, whereas the most negative values were measured in fracture fills and fibrous calcite (Fig. 14D). Reef limestone shows a covariance between $\delta^{13} \mathrm{C}$ and $\delta^{18} \mathrm{O}$ of the heaviest values, while bedded limestone, Plattenkalk and Wattendorf beds follow a wide range of $\delta^{13} \mathrm{C}$ associated with a narrow spread of $\sim 2 \%$ for $\delta^{18} \mathrm{O}$. The largest data spread is in the biostrome interval (Fig. 14E), where $\delta^{13} \mathrm{C}$ shows the most negative values, similar to the fracture fills and fibrous cements (Fig. 14D). These very negative $\delta^{13} \mathrm{C}$ values occur in dolomite with calcite cement and dedolomite, but occasionally also in micritic limestone which is similar to the basinal facies (Fig. 6F), but not in reef dolomite (Fig. 4A). The few samples with negative dolomite
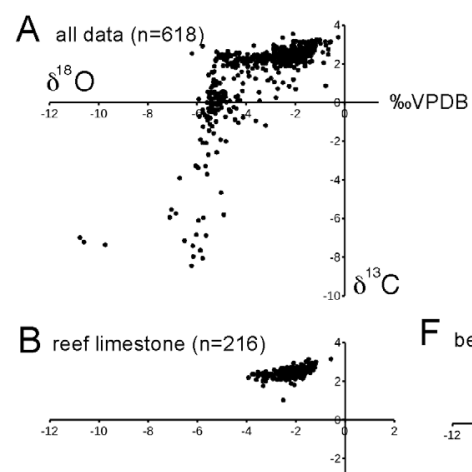

$F$ bedded limestone $(n=123)$
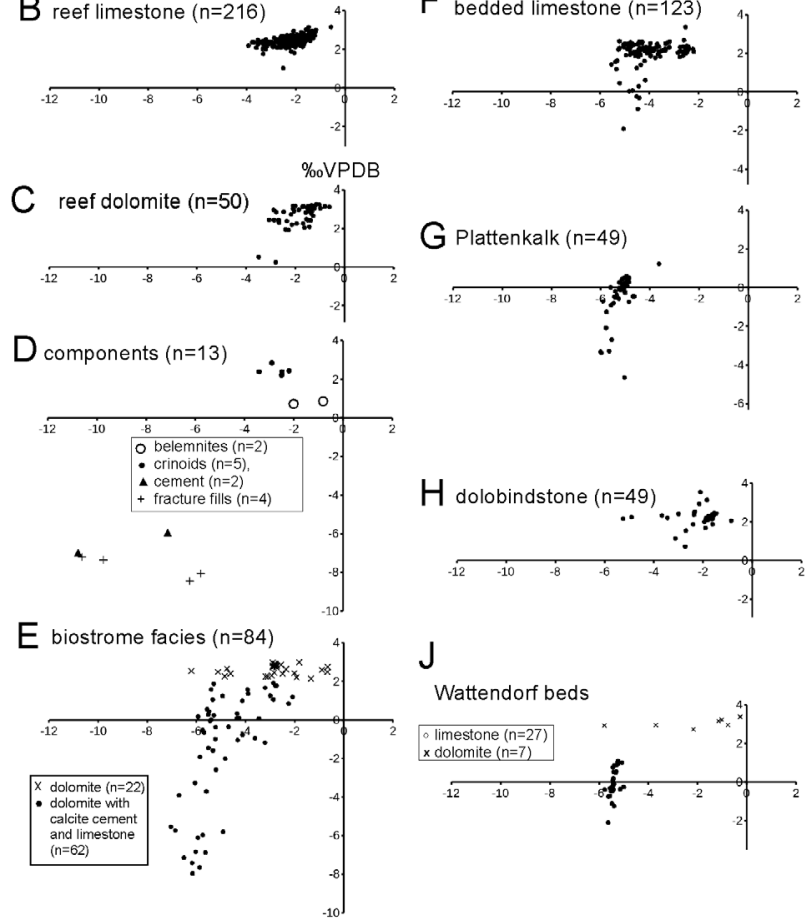

Fig. 14. Cross-plots of the stable isotope data of the study area showing a similar pattern similar to the "inverted J" (A), thought to be typical of freshwater diagenesis

B-J are the data of (A) split into facies and components 
$\delta^{13} \mathrm{C}$ probably are a mixture of calcite cement (with very negative stable isotope signal) and dolomite resulting from sampling. Negative $\delta^{13} \mathrm{C}$ values are typical for dedolomite of the biostrome facies, whereas pure dolomite always shows postive $\delta^{13} \mathrm{C}$ and slightly negative $\delta^{18} \mathrm{O}$ (Figs 6, $15 \mathrm{~A})$. The interval with very negative $\delta^{13} \mathrm{C}$ but consistent $\delta^{18} \mathrm{O}$ (around $-6 \%$ ) forms a distinct anomaly, which is best developed below the Plattenkalk, but locally such values occur in the Plattenkalk, too (Figs 5B: 6; 14G). Dolobindstone (Fig. 14H), reef dolomite (Fig. 14C) and the dolomitic Wattendorf beds (Fig. 14J) overlap, show exclusively positive $\delta^{13} \mathrm{C}$, and are heavier in $\delta^{13} \mathrm{C}$ and $\delta^{18} \mathrm{O}$ than limestone. This is particularly evident in the Plattenkalk section (Fig. 8B) and the comparison of dolobindstone and Plattenkalk (Fig. 11). In basinal facies the stable isotope pattern shows a general upward decrease of $\delta^{18} \mathrm{O}$ from $\sim-2$ to $-6 \%$, whereas a gradual decrease in $\delta^{13} \mathrm{C}$ is observed somewhat higher in the succession (Fig. 4). The XRD analyses confirm that dolomite is always heavier in $\delta^{13} \mathrm{C}$ and $\delta^{18} \mathrm{O}$ than limestone (Figs $8,15 \mathrm{~A}$ ). The negative $\delta^{18} \mathrm{O}$ and low $\delta^{13} \mathrm{C}$ values also prevail in the Wattendorf beds (Fig. 14D), but $\delta^{13} \mathrm{C}$ shows a slight upward increase of values and is heavier in
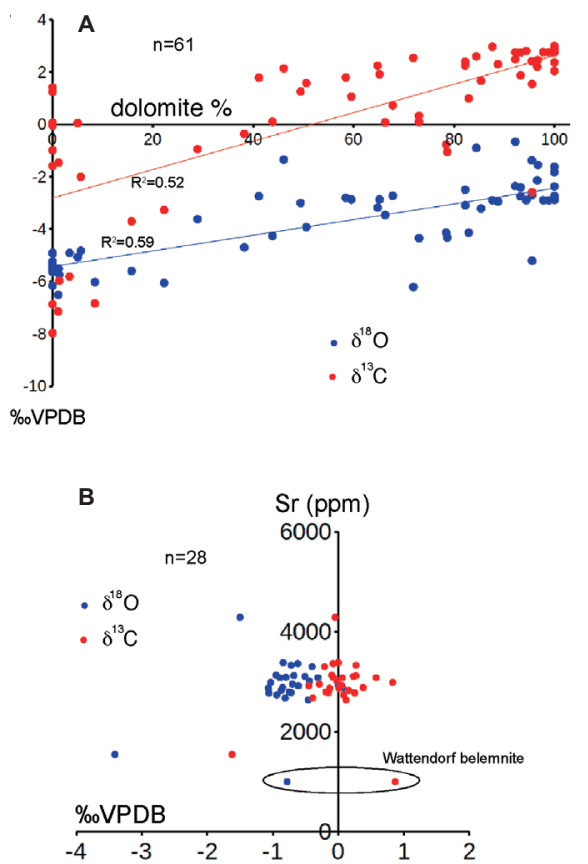

Fig. 15A. Cross-plot of the stable isotope values versus composition determined by XRD measurements. $\delta^{13} \mathrm{C}$ can vary considerably (between -8 and $+2 \%$ ), whereas $\delta^{18} 0$ shows covariance with calcite content and a slightly better correlation coefficient. B. Cross-plot of the stable isotope data versus $\mathrm{Sr}$ concentrations from belemnites of Nusplingen

For location, see Fig. 1A; data from Hättig et al., 2019. The belemnite from the Wattendorf Plattenkalk overlaps the Nusplingen belemnite isotope data, but the Sr concentration is lower the upper part of the reef flank (Fig. 8). The hand specimens of Plattenkalk and dolobindstone show nearly consistent $\delta^{13} \mathrm{C}$ and $\delta^{18} \mathrm{O}$ (Fig. 11), but show an average $\delta^{18} \mathrm{O}$ difference of $\sim 3.5 \%$ o $(\sim 2.5 \%$ if corrected for phosphoric acid fractionation) and a $\delta^{13} \mathrm{C}$ difference of $\sim 1.5 \%$. Minor covariant stable isotope excursions are correlated with thin grainstone beds in the Plattenkalk (Fig. 11A). The dolobindstone shows almost invariant values (Fig. 11B). The stable isotope values measured in the studied Plattenkalk are similar those of the Nusplingen Plattenkalk, which is slightly younger in age (Latest Late Kimmeridgian) $(\sim+0.5 \%$ and $-5.5 \%$ for $\delta^{13} \mathrm{C}$ and $\delta^{18} \mathrm{O}$, respectively; Stevens et al., 2014; Hättig et al., 2019). Reef limestone shows a very consistent $\delta^{13} \mathrm{C}$ and a minor excursions of $\delta^{18} \mathrm{O}$ (Fig. 16). A slight but steady upward increase in $\delta^{13} \mathrm{C}$ is observed and a slight covariance of the most positive isotope values (Fig. 14B). A similar trend can be inferred from the $\delta^{13} \mathrm{C}$ values of the Plattenkalk and is best reflected in the difference between the upper part of the reef flank and the basinal section (Fig. 8). Fracture fills and calcite cement show the most negative stable isotope values, crinoid ossicles the most positive $\delta^{13} \mathrm{C}$ of calcite. Belemnite data from Wattendorf and Nusplingen overlap, too (Fig. 15B). Wattendorf belemnites show $\delta^{18} \mathrm{O}$ values comparable to those of the reef limestone, but have lower $\delta^{13} \mathrm{C}$ (Fig. 14D). The overall stable isotope pattern is similar to the so-called "inverted J" trend (Lohmann, 1987; Fig. 14A), which is thought to be typical for freshwater diagenesis. Freshwater provides an isotopic signature with a narrow range of $\delta^{18} \mathrm{O}$ values and a broad range of $\delta^{13} \mathrm{C}$ values (e.g., Saller, 2006).

\section{ISOTOPE LOG CORRELATION}

Similar to what has been observed in the Jurassic rocks of the Swabian Alb Jurassic by Ruf et al. (2003), it is possible to correlate the stable isotope profiles of the studied sections within and between the Wattendorf and Altenberg areas, $\sim 20 \mathrm{~km}$ apart (Fig. 16). Correlation is possible within the reef facies and within the basinal succession, but questionable across these facies. In the reef sections, both isotope profiles show an almost invariant $\delta^{13} \mathrm{C}$ with a slight upward increase of $\sim 0,5 \%$, whereas the more serrated $\delta^{18} \mathrm{O}$ log allows the subdivision into several intervals. A metre-thick argillaceous interval in the drill cores of the reef facies is correlative with a similar interval in a quarry $3 \mathrm{~km} \mathrm{~W}$ (cf. Meyer, Schmidt-Kaler, 1989) and allows the definition of the top of Malm $\delta 1+2$. This indicates only minor differences in water depth between reef top and basin floor, but about 50-60 m difference in water depth in the interval when Plattenkalk was deposited. This correlatability of isotope logs is similar to the example from the Swabian Jurassic, where correlation 


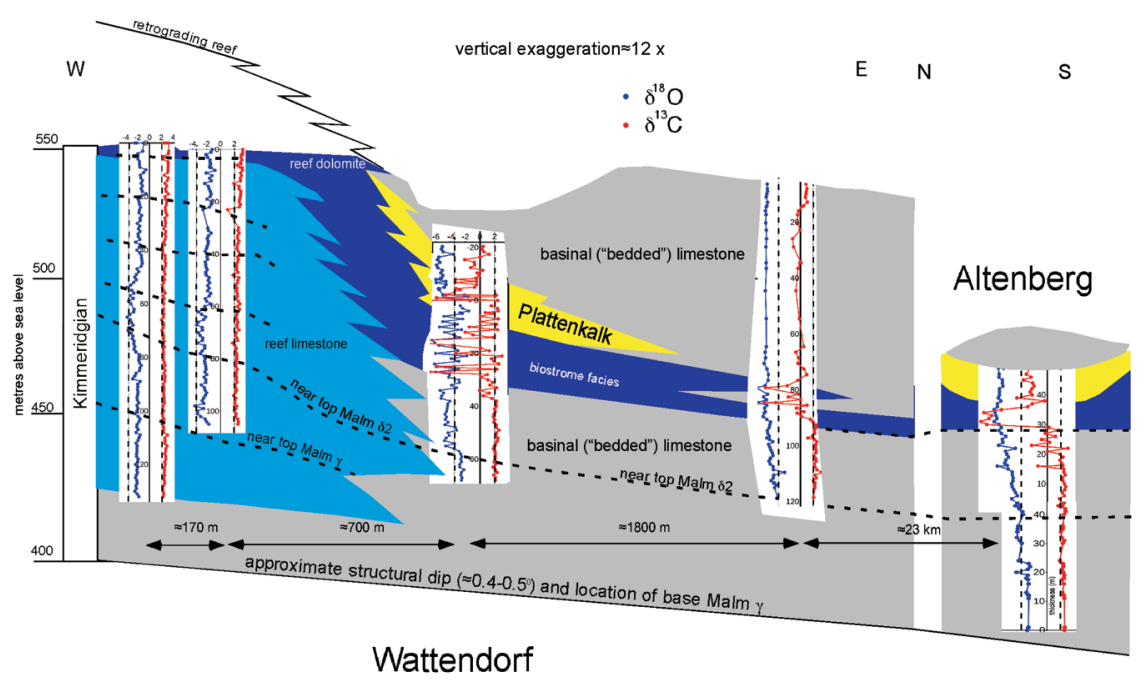

Fig. 16. Isotope log correlation of the reef-to-basin transect of the Wattendorf area and Altenberg

The isotope logs show upward covariance. The logs of the reef facies show almost invariant $\delta^{13} \mathrm{C}$ isotopes, but correlation of intervals is possible based on $\delta^{18} 0$ (stippled black lines). The top of the Malm $\gamma$ and Malm $\delta 1+2$ in the reef facies is inferred from a marly interval in the cored reef facies correlative with a similar interval in a quarry about $3 \mathrm{~km}$ west of Wattendorf (Meyer, Schmidt-Kaler, 1989). Log-based correlation with the basinal facies is not possible. The basinal facies show an upward decrease in stable isotope values, which can be correlated with the Altenberg section $\sim 23 \mathrm{~km}$ distant. Directly below the Plattenkalk the $\delta^{13} \mathrm{C} \log$ shows a pronounced $\delta^{13} \mathrm{C}$ anomaly. The stippled vertical lines in the stable isotope logs are for orientation at -3.5 and $+2 \%$ o

is mainly based on $\delta^{18} \mathrm{O}$, too. The basinal sections show $\delta^{13} \mathrm{C}$ similar to that of the reef facies in the lowest part, and decreasing values stratigraphically upward with a strongly serrated $\delta^{13} \mathrm{C} \log$ corresponding to the biostrome facies. $\delta^{18} \mathrm{O}$ shows less variability in this interval. It is also conspicuous that the Wattendorf area and the Altenberg section, $\sim 23 \mathrm{~km}$ further south, show the same log shape and values and very similar thickness of individual units (Figs 4, 8, 9).

\section{Sr ISOTOPES}

${ }^{87} \mathrm{Sr} /{ }^{86} \mathrm{Sr}$ ratios range from 0.706677 to 0.709055 (Fig. 17A). The current best estimate for Late Kimmeridgian seawater is a range from 0.707685 to 0.707696 (the red bar in Fig. 17). It is evident that most values are slightly elevated (the values above the seawater bar in Fig. 17), some fall exactly on this range, and some measurements show lower ${ }^{87} \mathrm{Sr} /{ }^{86} \mathrm{Sr}$ ratios. Most of the elevated values occur in the reef

Fig. 17A. Coss-plot of the ${ }^{87} \mathrm{Sr} /{ }^{86} \mathrm{Sr}$ ratios versus Sr concentration of the studied carbonates and tooth apatite. Most data are slightly radiogenic with respect to Late Kimmeridgian seawater (red bar delineating minimum and maximum values, except for the New Zealand values, of Wierzbowski et al., 2017). The general trend is that ${ }^{87} \mathrm{Sr} /{ }^{86} \mathrm{Sr}$ increases with decreasing $\mathrm{Sr}$ concentration. This is either due to a freshwater layer above the marine water column, due to the preferential loss of the lighter Sr isotope during diagenesis, or sample contamination with clay minerals. B. Cross-plot of the stable isotope data versus ${ }^{87} \mathrm{Sr} /{ }^{86} \mathrm{Sr}$. These parameters do not show any correlation dolomite and bedded limestone. Plattenkalk and Wattendorf beds are close to the marine values but can be slightly elevated or lowered (the values below the red bar in Fig. 17).

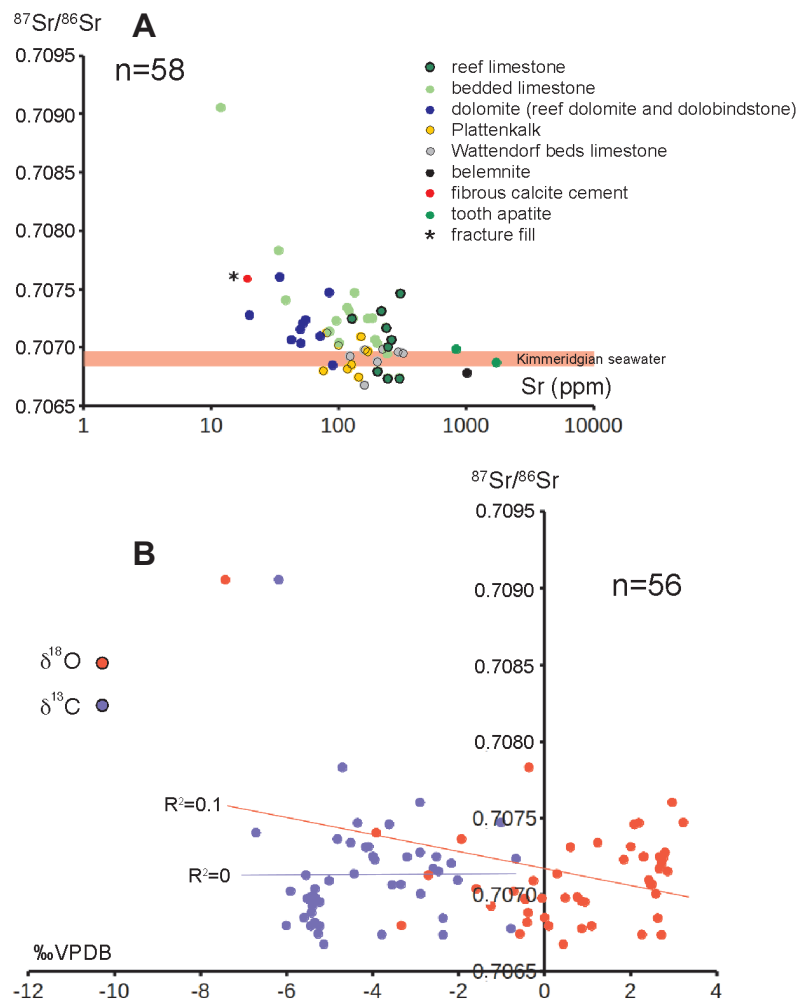


The most radiogenic value is from a bedded limestone of the Kleinziegenfeld section with a stable isotope signal indistinguishable from the rocks above and below (Fig. 7B). Samples from tooth apatite plot on the seawater curve, while the measured belemnite and some samples from the (bedded) limestone and the Wattendorf beds plot slightly below (Fig. 17B). Sr concentrations range from $\sim 1500 \mathrm{ppm}$ in tooth apatite to $\sim 10 \mathrm{ppm}$ in the limestone with the highest ${ }^{87} \mathrm{Sr} /{ }^{86} \mathrm{Sr}$ ratio. There is no correlation between ${ }^{87} \mathrm{Sr} /{ }^{86} \mathrm{Sr}$ and stable isotope values (Fig. 17B).

\section{DISCUSSION}

\section{THE MARINE CARBON AND OXYGEN ISOTOPE REFERENCE}

The $\delta^{18} \mathrm{O}$ values of Kimmeridgian seawater can only be estimated to have been around-1\% SMOW (polar ice-free world, Shackleton, Kennett, 1975). A calcite deposited from such seawater would theoretically have a similar composition on the PDB scale. No reference data exist from the Franconian Alb. The Swabian Alb Jurassic shows $\delta^{18} \mathrm{O}$ with similarly negative values as the upper part of the studied bedded limestone, $\sim-3$ to $-5 \%$, whereas $\delta^{13} \mathrm{C}$ is +1 to $+2 \%$ (Ruf et al., 2003). Reference Kimmeridgian $\delta^{13} \mathrm{C}$ values (2 to $4 \%$ ) of well-preserved fossils (see Brigaud et al., 2008 and Zuo et al., 2019) are similar to the values of crinoid ossicles from the study area (Fig. 14D). Slightly lower $\delta^{13} \mathrm{C}$ values (1 to $3 \%$ ) are, however, reported from the Upper Kimmeridgian bulk carbonates of Tethyan and peri-Tethys areas (Price et al., 2016; Wierzbowski, 2019). It might be argued that the belemnite $\delta^{13} \mathrm{C}$ (Fig. 15A), centring around $0 \%$, records open marine conditions and reflects the „true“ marine $\delta^{13} \mathrm{C}$, but this could be a vital effect (Stevens et al., 2014). It is thus clear that many measured isotope values record deviations from an expected "normal" marine isotope signal.

\section{THE INVERTED J TREND}

The inverted $\mathrm{J}$ trend of the stable isotopes could be considered as an argument in favour of freshwater diagenesis (e.g., Saller, 2006). High burial temperatures can be safely excluded, because the Lower Jurassic rocks of the Franconian Alb were never exposed to burial temperatures of $>50$ $60^{\circ} \mathrm{C}$ (Kreiensiek, 2019). The mostly elevated ${ }^{87} \mathrm{Sr} /{ }^{86} \mathrm{Sr}$ would seamlessly fit a freshwater interpretation. Such a scenario cannot be excluded, but is unlikely. The Franconian Jurassic does not show any traces of intraformational exposure, but probably emerged in the Tithonian. The main problem with the freshwater scenario is that the inverted $\mathrm{J}$ trend is caused exclusively by data from basinal environments. It is difficult to conceive that meteoric diagenesis could have dominated the deeper-water facies (for a similar observation from the Swiss Jura, see Colombie et al., 2011). This calls for a different scenario to explain the covariance of the stable and the mostly elevated Sr ratios.

\section{BASINAL LIMESTONE}

Covariance of stable isotopes is not only restricted to freshwater but can have a variety of causes, which are summarized in Table 2. These include biological and kinetic fractionation, increasing brackish conditions of the water column, or ageing effects of the water column, or a combination of different factors. Kinetic effects due to vital fractionation would produce such a trend for $\delta^{13} \mathrm{C}$ limited to the microbial facies in the dololaminite, reef dolomite and biostrome facies, but this is not observed. The problem of the depositional mineralogy, which is unknown, adds to this uncertainty. Gradually more brackish conditions of the water column are very unlikely, too, because of the normal marine fauna in the Plattenkalk (see Arratia et al., 2015). Marine organisms would probably not tolerate a salinity of $\sim 15-$

Compilation of possible effects on the stable isotope composition of marine carbonates, modified after Colombie et al. (2011)

Table 2

\begin{tabular}{|c|c|c|c|}
\hline Process & Controls & $\delta^{13} \mathrm{C}$ & $\delta^{18} \mathrm{O}$ \\
\hline \multirow{6}{*}{ Fractionation } & mineralogy (HMC and aragonite vs. LMC) & + & + \\
\hline & temperature increase & $\mathrm{o}$ & - \\
\hline & kinetic effects (biological and growth rate) & - & - \\
\hline & freshwater discharge & - & - \\
\hline & metabolic effects, respiration & + & o \\
\hline & organic matter oxidation, methanogenesis & - & o \\
\hline \multirow{3}{*}{ Changes in seawater/porewater composition } & organic matter production and burial & + & o \\
\hline & evaporation & + & + \\
\hline & water mass ageing & - & - \\
\hline \multirow{3}{*}{ Diagenesis } & syndepositional diagenesis & + & + \\
\hline & early meteoric diagenesis & - & - \\
\hline & burial diagenesis & + & - \\
\hline
\end{tabular}

$(+)$ an enrichment of the heavier isotope; (-) a depletion of the heavier isotope; (o) no change. 
$20 \mathrm{ppt}$, which would result from a calcite with a $\delta^{18} \mathrm{O}$ of -5 to $-6 \%$, a typical value of Plattenkalk (cf. calculation in Wierzbowski et al., 2017). The most plausible explanation is, at this moment, a totally different effect, namely ageing of the bottom waters. Oxidation of organic matter and sulphate reduction causes increase in ${ }^{12} \mathrm{C}$ with increasing depth and water mass age, and also can cause shifts of $\delta^{18} \mathrm{O}$ to more negative values (Pierre et al., 1991). This could explain the negative excursions in the semi-closed or closed depressions between the reefs. It should also be noted that the measured bulk rock isotope signal is not necessarily identical to that of the original lime mud or the marine pore fluids. It is the result of interaction between pore fluids and sediment particles during recrystallization (Patterson, Walter, 1994), which may lead to early diagenetic shifts of the primary sediment and pore fluid signal.

\section{Sr ISOTOPES}

Another effect may have been superimposed on water mass ageing. Freshwater could have influenced the isotope signal in a form not usually considered for carbonates. It is likely that the lime mud, which was precursor to the Plattenkalk (and probably the other micritic facies, too) is at least partly a "pelagic rain" produced higher in the water column or winnowed from the reef tops (Viohl, 2015a). Micrite originating in a boundary zone between a freshwater layer (e.g., Keupp, 1976), produced by continental run-off, and the normal marine water column, would show a shift towards more negative $\delta^{18} \mathrm{O}$ and $\delta^{13} \mathrm{C}$ values. This option also could explain the often radiogenic Sr values. Riverine continental run-off may have had varying, but generally radiogenic ${ }^{87} \mathrm{Sr} /{ }^{86} \mathrm{Sr}$ (but lower $\mathrm{Sr}$ concentration than seawater), whereas pelagic organisms (fish, belemnites) had normal marine to slightly more negative values. This assumption is not entirely new. In fact $\delta^{18} \mathrm{O}$ of shark teeth measured from the Swiss Jura also suggests freshwater influence (Leuzinger et al., 2015). Freshwater influence deduced from continental runoff is questioned, however, by observations from large modern estuaries, where seawater has a normal marine ${ }^{87} \mathrm{Sr} /{ }^{86} \mathrm{Sr}$ in spite of significant mixing with freshwater (Kuznetsov et al., 2012). An equally plausible explanation is analytical contamination with ${ }^{87} \mathrm{Sr}$ (and $\mathrm{Rb}$ ) produced by leaching of clay minerals during sample preparation (Simo et al., 1994). This would easily explain why the Wattendorf beds and the Plattenkalk (with the lowest clay content) show only minor deviations from the marine signal, whereas all other facies can be more or less radiogenic. Unfortunately, this option cannot be verified because $\mathrm{Rb}$ was not measured, but it is considered the most likely at this moment. The low ${ }^{87} \mathrm{Sr} /{ }^{86} \mathrm{Sr}$ ratios are more difficult to explain. The data are similar to those from the Oxfordian, the Phanerozoic minimum of seawater ${ }^{87} \mathrm{Sr} /{ }^{86} \mathrm{Sr}$ (Wierzbowski et al., 2016), but the analysed rocks are certainly Upper Kimmeridgian, where values should be slightly higher. The low values could be caused by a slightly ${ }^{87} \mathrm{Sr}$ depleted water column due to water mass ageing, similar to, but the reverse of, what has been inferred from the ${ }^{87} \mathrm{Sr} /{ }^{86} \mathrm{Sr}$ of the Triassic Muschelkalk (which is slightly more radiogenic than Triassic seawater: Korte et al., 2003), or from ascending fluids derived from the diagenesis of Oxfordian rocks below. Most cases discussed above do not necessitate diagenetic changes resulting from fluid flow, and $\mathrm{Sr}$ isotopes are fully compatible with the assumption that the isotope signal was not modified by freshwater diagenesis.

\section{DOLOMITE AND ISOTOPIC EQUILIBRIA}

The Upper Jurassic dolomite of southern Germany has been interpreted as the result of a multi-phase process initiated by seawater-freshwater mixing (Koch, Schorr, 1986), partly linked to high temperature fluid migration (Mraz et al., 2019) or fluids derived from mechanical compaction (Reinhold, 1998). Although none of these models can be validated or discarded with the data of this study, the first model would not explain why the Swabian Jurassic is very dolomite-poor in spite of very similar stratigraphic development. Elevated burial temperatures can be excluded, as discussed above, but higher temperatures cannot be excluded for some fracture-related cements, which were not studied here because of their rareness. The Reinhold (1998) model would produce subhorizontal or lateral facies changes from limestone to dolomite. The regional dolomite front is, in fact, essentially stratiform. Dolomite is, however, restricted to the reef facies, whereas basinal facies are nearly always limestone, and the overall dolomite abundance decreases stratigraphically downward (Niebuhr, Pürner, 2014), not upward as expected in the Reinhold (1998) model. It has often been argued that the preferential dolomitization in reef facies is due to enhanced (primary and fracture) porosity favouring fluid flow. In the study area, nearly all potential dolomite precursors, seen in the calcareous reef facies, are tight (see section Reef limestone), with estimated negligible porosity and permeability, but porosity measurements are not available. The assumption that more favourable conditions for flow of dolomitizing fluids existed in the reef and biostrome limestone is, therefore, problematic.

A much simpler explanation for the studied dolomite can be suggested based on the isotopes of this study. Because dolomite is restricted to the boundstone facies (dolobindstone, biostrome and reef facies) it could have formed as very high $\mathrm{Mg}$ calcite (VHMC, or protodolomite induced by 
microbes) which recrystallized to dolomite, preserving the depositional isotope signal. Microbial protodolomite has been documented from modern environments (Vasconcelos et al., 1995; Vasconcelos, McKenzie, 1997). A VHMC is expected to be enriched in $\delta^{13} \mathrm{C}$ by $1-2 \%$ with respect to coprecipitated LMC (e.g., Jimenez-Lopez et al., 2006). Dolomite should also be heavier in $\delta^{18} \mathrm{O}$, but the estimates or calculations range from $0.6 \%$ (Zheng, 1999) to 3-6\% (Land, 1980; Jimenez-Lopez et al., 2004). In fact, the observed isotopic differences between calcareous Plattenkalk (average $\delta^{13} \mathrm{C} 0.15 \%, \delta^{18} \mathrm{O}-5 \%$ ) and reef dolomite and dolobindstone (average $\delta^{13} \mathrm{C} 2.2 \%$, $\delta^{18} \mathrm{O}-1.7 \%$; Figs 8,11 ) are $\sim 1.9 \%$ for $\delta^{13} \mathrm{C}$ and $\sim 3.2 \%$ for $\delta^{18} \mathrm{O}$. These values overlap the predictions for isotopic differences between co-precipitated calcite and dolomite and suggest that studied dolomite facies and the basinal facies including Plattenkalk with the more negative values were deposited from isotopically similar fluids. By contrast, reef limestone and reef dolomite apparently did not form in isotopic equilibrium, because they show largely overlapping stable isotope data (Fig. 14B, C). Reef dolomite should be more positive than reef limestone if they recorded similar fluids. Calcareous Plattenkalk and reef limestone show an isotopic difference $\left(\delta^{13} \mathrm{C} \sim 1.5 \%\right.$ and $\delta^{18} \mathrm{O} \sim 2-4 \%$ ) similar to that predicted for dolomite and limestone. These facies are calcitic, and the difference cannot be due to fractionation but, in an ageing scenario, is rather the effect of isotopic water mass stratification. This could indicate that the isotopically negative, aged water masses intermittently covered the entire submarine relief when the VHMC formed. The Plattenkalk is entirely dolomitic on the shallow parts of the dolomitic reef flanks (Figs 5A, 8A), but a limestone-dolomite mix in the depression itself (Fig. 8B). This suggests a polarity, with the dolomite precursor forming in shallower water than limestone.

\section{ORIGIN AND SIGNIFICANCE OF THE ISOTOPE ANOMALY}

In the biostrome facies and partly within the Plattenkalk, the isotopes do no longer covary, and $\delta^{13} \mathrm{C}$ can become more negative than $\delta^{18} \mathrm{O}$, which remains unchanged around $-6 \%$. This is reflected in the vertical $\delta^{13} \mathrm{C}$ trend in the diagram of Fig. 14A. It is a largely diagenetic anomaly caused by calcite cement and dedolomite. In a restricted basin an oxygen minimum zone (OMZ) appears a likely candidate to explain the absence of bottom life. Such a zone is dominated by two processes, namely sulphate reduction and methanogenesis, whereby methanogenesis is the last step in the bacterial decomposition of organic matter. Both processes often take place within the sediment column, and where the associated
OMZ is located at the seabed, benthic life is virtually impossible (e.g., Reichart et al., 1998). Methanogenesis appears as the most likely cause for these low $\delta^{13} \mathrm{C}$ values. It occurred mainly within the sediment column and is suggested to account for the geochemical signal of the calcite nodules and the dedolomite of the biostrome facies. In the Plattenkalk, the zone of methanogenesis was probably slightly above the seabed, explaining why methanogenesis is only rarely reflected in stable isotope values. The absence of oxygen near the seabed was responsible for the prefect preservation of various fossils. Rare benthos, such as the bivalve Aulacomyella (Mäuser, 2015), in the Wattendorf Plattenkalk is consistent with slight fluctuation of the OMZ. The negative peaks in the detrital grainstones (Fig. 11A) are probably a mix value of more positive reef derived particles and more negative cements (cf. Scharfenberg, 2011). Methanogenesis associated with an OMZ is an alternative to the traditional hypersaline bottom water model (see also Fürsich et al., 2007a, b). If evaporation caused density stratification of the water column, more positive than normal marine $\delta^{18} \mathrm{O}$ is expected in the shallowest part of the succession, the reefs, but this is not observed. The dedolomite is more difficult to explain with current models. Dedolomite normally shows $\delta^{13} \mathrm{C}$ values similar to equivalent calcite (Schoenherr et al., 2018) and is thought to require the flow of Ca-rich fluids at low temperature to transform a dolomite into limestone. Ca-rich fluids are thought to be derived from evaporite diagenesis, but there is no evidence for evaporites in the south German Jurassic. This would mean that Jurassic Ca-rich brines came from below (Zechstein or Triassic evaporites), but this would imply fracture-related evaporite diagenesis, which is unknown from the Jurassic strata of southern Germany. The exact origin of the studied dedolomite must, therefore, remain undecided here, but was possibly associated with sulphate reduction, which favours carbonate dissolution (Meister, 2013) and would explain the large vugs and hollow dolomite rhombs. This would suggest a very early diagenetic dedolomitization.

\section{COMPARISON WITH THE MIDDLE VOLGIAN OWADÓW-BRZEZINKI KONSERVAT-LAGERSTÄTTE IN POLAND}

The Owadów-Brzezinki quarry in central Poland provides, until now, the only other example of a continuous isotope profile of a Jurassic Konservat-Lagerstätte and its stratigraphic frame (Wierzbowski et al., 2016). The quarry exposes a metre-thick succession of partly laminated, micritic limestone, the Konservat-Lagerstätte, framed by entirely micritic limestone above and below, locally with hard- 
grounds and evaporite pseudomorphs. The main difference with the Wattendorf and Altenberg examples is the palaeographical setting in a lagoonal environment with more influence of the boreal fauna. The local depressions and frame of reefs, typical of the German examples, are not developed. All occurrences have one or two stable isotope anomalies below the Konservat-Lagerstätte (Fig. 18). In Poland, the anomaly is considered to document freshwater influence (Wierzbowski et al., 2016) and occurs in micritic, lagoonal limestone, not in a depression nor associated with a succession of dedolomite and calcite-cemented dolomite such as on the Franconian Alb. The observation that the isotope anomaly occurs in examples on the Franconian Alb and in Poland might be a coincidence or could suggest a systematic relationship between Konservat-Lagerstätte and anomaly. Freshwater is plausible for the flat, lagoonal Polish situation, but problematic for the German examples because it would mean that the less dense fluid occurred at the bottom of depressions.

\section{PLATTENKALK SCENARIO}

The presently most likely scenario suggests a slight modification of the current model for the origin of the south German Upper Jurassic Konservat-Lagerstätten. The isotope data of this study are compatible with a marine environment with normal salinity. Basin restriction developed gradually and is reflected in stable isotope values decreasing stratigraphically upward in a $\sim 40 \mathrm{~m}$-thick interval. Restriction culminated in methanogenesis in the sediment, and an OMZ in the water column when Plattenkalk was deposited. This is reflected in low $\delta^{13} \mathrm{C}$ observed in dedolomite, calcite cement and rock matrix. The absence of Plattenkalk in the deepest part of the Wattendorf depression also argues against hypersaline bottom waters as cause for the rareness of benthos. It is conceivable that the oxygen minimum zone was limited to the reef embayment (Fig. 3A), or that the centre of the depression (Fig. 9) was below the OMZ. Low organic productivity of the aged water column (cf. Viohl, 2015c) fa-

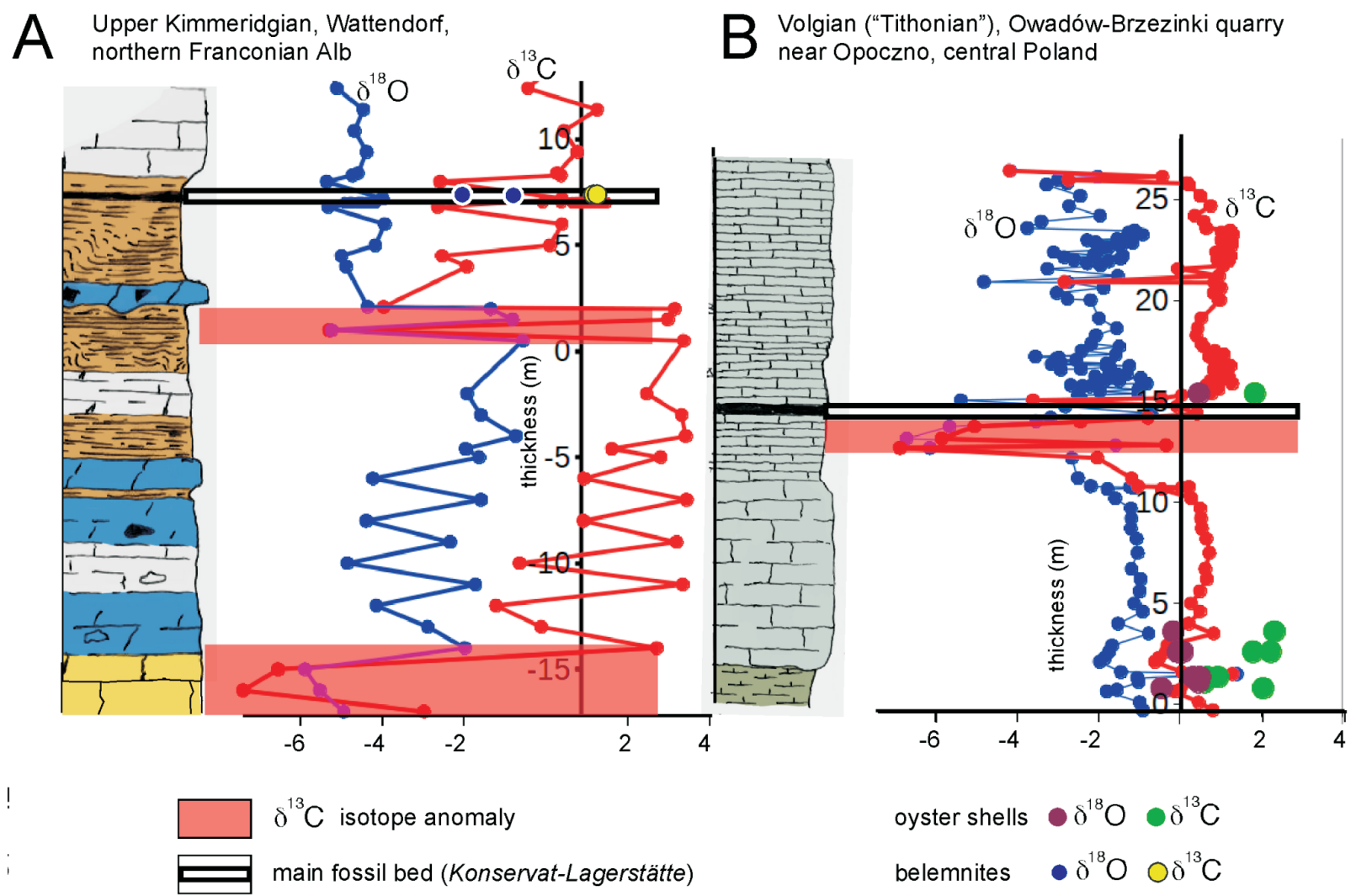

Fig. 18. Comparison of the lithology and isotope profiles of two Upper Jurassic Konservat-Lagerstätten, $700 \mathrm{~km}$ apart

Both occurrences show a marked $\delta^{13} \mathrm{C}$ anomaly below the main fossil beds. The anomaly is interpreted as of freshwater origin in the Polish example, the German example is interpreted as due to methanogenesis 
voured the development of an organic-poor Konservat-Lagerstätte, dissimilar from its Lower Jurassic counterpart, the "Posidonia Shale", in its light colour and negligible TOC content.

\section{CONCLUSIONS}

Two general conclusions can be drawn from this study. Firstly, stable oxygen isotopes from bulk rock analyses are, contrary to common belief, not meaningless because particularly dense, micritic limestone can preserve an early marine diagenetic signal. An "inverted J trend" can have different causes, such as ageing of water masses in restricted basins and does not necessarily indicate alteration by freshwater diagenesis. Secondly, $\mathrm{Sr}$ isotopes should always be supported by $\mathrm{Rb}$ analysis to identify analytical, unintended sample contamination by clay minerals. Radiogenic Sr isotopes do not automatically support the assumption that diagenetic fluids have modified a depositional signal unless supported by $\mathrm{Rb}$ analysis. A specific conclusion is that the Wattendorf Konservat-Lagerstätte documents an oxygen minimum zone in the water column (see also Fürsich et al., $2007 \mathrm{a}, \mathrm{b})$ rather than hypersaline conditions caused by evaporation in an arid climate.

Acknowledgements. We thank Helmut Schorr and Dr. Markus Schorr (Andreas Schorr Dolomit- und Kalkwerk Gmbh \& Co KG) for the permission to access the quarry and to study and sample the drill cores. Winfried Werner (München) is thanked for slabbing and photographing core material and for discussions. Corelab (Abu Dhabi) provided the XRD measurements, Fred Türck (Clausthal) the XRF measurements, Nicole Nolte-Moser (Göttingen) the Sr isotope measurements, and Michael Joachimski (Erlangen) the carbon and oxygen isotope measurements. Franz Fürsich (Erlangen), Tadeusz Peryt and Hubert Wierzbowski (Warszawa), who also provided the original isotope data from the Owadów-Brzezinki quarry, reviewed this paper. The support of all institutions and individuals is gratefully acknowledged.

\section{REFERENCES}

ARRATIA G., SCHULTZE H.-P., TISCHLINGER H., VIOHL G. (eds.), 2015 - Solnhofen - ein Fenster in die Jurazeit. Verlag Dr. Friedrich Pfeil, München.

BARTHEL K.W., 1969 - Die obertithonische, regressive Flachwasser-Phase der Neuburger Folge in Bayern. Abhandlungen der Königlich Bayerischen Akademie der Wissenschaften, Mathematisch-Naturwissenschaftliche Klasse, Neue Folge, 142: $1-174$.
BAUSCH W., HOEFS J., 1972 - Die Isotopenzusammensetzung von Dolomiten und Kalken aus dem siiddeutschen Malm. Contributions to Mineralogy and Petrology, 37: 121-130.

BRIGAUD B., PUCÉAT E., PELLENARD P., VINCENT B., JOACHIMSKI M.M., 2008 - Climatic fluctuations and seasonality during the Late Jurassic (Oxfordian-Early Kimmeridgian) inferred from $\delta^{18} \mathrm{O}$ of Paris Basin oyster shells. Earth and Planetary Science Letters, 273: 58-67.

COLOMBIÉ C., LÉCUYER C., STRASSER A., 2011 - Carbon and oxygen-isotope records of palaeoenvironmental and carbonate production changes in shallow-marine carbonates (Kimmeridgian, Swiss Jura). Geological Magazine, 148: 133-153.

FESEFELDT K., 1962 - Schichtenfolge und Lagerung des oberen Weißjura zwischen Solnhofen und der Donau (Südliche Frankenalb). Erlanger Geologische Abhandlungen, 46: 1-80.

FÜRSICH F., MÄUSER M., SCHNEIDER S., WERNER W., 2007a - The Wattendorf Plattenkalk (Upper Kimmeridgian) - a new conservation lagerstätte from the northern Franconian Alb, southern Germany. Neues Jahrbuch für Geologie und Paläontologie, Abhandlungen, 245: 45-58.

FÜRSICH F., WERNER W., SCHNEIDER S., MÄUSER M., 2007b - Sedimentology, taphonomy and paleogeography of a laminated plattenkalk of the northern Franconian alb (southern Germany). Palaeogeography, Palaeoclimatology, Palaeoecology, 243: 92-117.

HÄTTIG K., STEVENS K., SCHWEIGERT G., MUTTERLOSE J., 2019 - Evaluation of shark tooth diagenesis - screening methods and the application of their stable oxygen isotope data for palaeoenvironmental reconstructions. Journal of the Geological Society, 176: 482-491.

HEGENBERGER W., SCHIRMER W., 1967 - Geologische Karte von Bayern $1: 25,000$ und Erläuterungen zu Blatt Nr. 5932 Ützing. München.

HERRMANN A.D., GORDON G.W., ANBAR A.D., 2018 - Uranium isotope variations in a dolomitized Jurassic carbonate platform (Tithonian; Franconian Alb, Southern Germany. Chemical Geology, 497: 41-53.

HOMUTH S., 2014 - Aufschlussanalogstudie zur Charakterisierung oberjurassischer geothermischer Karbonatreservoire im Molassebecken [Unpubl. PhD thesis]. Technische Universität Darmstadt.

JIMENEZ-LOPEZ C., ROMANEK C.S., HUERTAS F.J., OHMOTO H., CABALLERO E., 2004 - Oxygen isotope fractionation in synthetic magnesian calcite. Geochimica et Cosmochimica Acta, 68: 3367-3377.

JIMENEZ-LOPEZ C., ROMAEK C.S., CABALLERO E., 2006 Carbon isotope fractionation in synthetic magnesian calcite. Geochimica et Cosmochimica Acta, 70: 1163-1171.

KACZMAREK S.E., SIBLEY D.F., 2011 - On the evolution of dolomite stoichiometry and cation order during high-temperature synthesis experiments: An alternative model for the geochemical evolution of natural dolomites. Sedimentary Geology, 240: $30-40$.

KEUPP H., 1976 - Der Solnhofener Plattenkalk - Ein neues Modell seiner Entstehung. Naturkundliche Gesellschaft Nürnberg, 1976: 19-36. 
KOCH R., SCHORR M., 1986 - Diagenesis of Upper Jurassic sponge-algal reefs in SW Germany. In: Reef diagenesis (eds. J.H. Schroeder, B. Purser): 224-244. Springer, Berlin.

KORTE C., KOZUR H., BRUCKSCHEN P., VEIZER J., 2003 Strontium isotope evolution of Late Permian and Triassic seawater. Geochmica et Cosmochimica Acta, 67: 47-62.

KREIENSIEK A., 2019 - Untersuchung von Reifegraden von Gesteinen des Fränkischen Jura [Unpubl. BSc Thesis]. Technical University Clausthal.

KUZNETSOV A.B., SEMIKHATOV M.A., GOROKOV I.M., 2012 - The Sr isotope composition of the world ocean, marginal and inland seas: Implications for the $\mathrm{Sr}$ isotope stratigraphy. Stratigraphy and Geological Correlation, 20: 501-515.

LAND L.S., 1980 - The isotopic and trace element geochemistry of dolomite: the state of the art. Society for Sedimentary Geology, Special Publications, 28: 86-110.

LEUZINGER L., KOCSIS L., BILLON-BRUYAT J.-P., SPEZZAFERRI, S., VENNEMANN T., 2015 - Stable isotope study of a new chondrichthyan fauna (Kimmeridgian, Porrentruy, Swiss Jura): an unusual freshwater-influenced isotopic composition for the hybodont shark Asteracanthus. Biogeosciences, 12: 6945-6954.

LIEDMANN W., 1992 - Diagenetische Entwicklung Süddeutscher Malmkarbonate - unter Berücksichtigung lumineszenzpetrographischer, fluid inclusions und geochemischer Untersuchungsmethoden [Unpubl. PhD thesis]. Universität Heidelberg.

LOHMANN K.C., 1987 - Geochemical patterns of meteoric diagenetic systems and their application to the study of paleokarst. In: Paleokarst (eds. N.P. James, P.W. Choquette): 58-80. Springer, Berlin.

MÄUSER M., 2015 - Die laminierten Plattenkalke von Wattendorf in Oberfranken. In: Solnhofen - ein Fenster in die Jurazeit (eds. G. Arratia et al.): 515-535. Verlag Dr. Friedrich Pfeil, München.

MÄUSER M., SCHIRMER W., SCHMIDT-KALER H., 2002 Obermainalb und fränkisches Bruchscholleland. Verlag Dr. Friedrich Pfeil, München.

McARTHUR J., 1994 - Recent trends in strontium isotope stratigraphy. Terra Nova, 6, 331-358.

MEISTER P.H., 2013 - Two opposing effects of sulfate reduction on carbonate precipitation in normal marine, hypersaline, and alkaline environments. Geology, 42: 499-502.

MEYER R.K.F., 1974 - Stratigraphie und Fazies des Frankendolomits (Malm). 2. Teil: Mittlere Frankenalb. Erlanger Geologische Abhandlungen, 96: 1-34.

MEYER R.K.F., 1979 - Geologische Karte von Bayern $1: 25,000$ Erläuterungen zum Blatt Nr. 6132 Buttenheim. Bayerisches Geologisches Landesamt, München.

MEYER R.K.F., 2015 - Lithostratigraphie der Solhofener Schichten (Weißjura Zeta 2a+2b, Unter-tithonium). In: Solnhofen ein Fenster in die Jurazeit (eds. G. Arratia et al.): 67-71. Verlag Dr. Friedrich Pfeil, München.

MEYER R.K.F., SCHMIDT-KALER H., 1992 - Wanderungen in die Erdgeschichte - Durch die Fränkische Schweiz. Verlag. Dr. Friedrich Pfeil.
MEYER R.K.F., SCHMIDT-KALER H., 1989 - Paläogeographischer Atlas des süddeutschen Malm. Geologisches Jahrbuch, 115: $1-77$.

MRAZ E., WOLFGRAMM M., MÖCK I., THURO K., 2019 Detailed fluid inclusion and stable isotope analysis on deep carbonates from the North Alpine Foreland Basin to constrain paleofluid evolution. Geofluids, 2019, Article ID 8980794.

MUDROCH A., 2001 - Fischzähne aus dem Oberjura Nordwesteuropas - Systematik, Biogeochemie und Palökologie [Unpubl. PhD thesis]. University of Hannover, Germany.

MUNNECKE A., WESTPHAL H., KÖLBL-EBERT M., 2008 Diagenesis of plattenkalk: examples from the Solnhofen area (Upper Jurassic, southern Germany). Sedimentology, 55, 1931-1946.

NIEBUHR B., PÜRNER T., 2014 - Plattenkalk und Frankendolomit - Lithostratigraphie der Weißjura-Gruppe der Frankenalb (außeralpiner Oberjura, Bayern). Schriftenreihe der Deutschen Geologischen Gesellschaft, 83, 5-71.

OOST A.P., de BOER P.L., 1994 - Tectonic and climatic setting of lithographic limestone basins. Geobios, 16: 321-330.

PATTERSON W.P., WALTER L.M., 1994 - Syndepositional diagenesis of modern platform carbonates: evidence from isotopic and minor element data. Geology, 22: 127-130.

PIERRE C., VERGNAUT-GRAZZINI C., FAUGERES J.C., 1991 - Oxygen and carbon stable isotope tracers of the water masses in the Central Brazil Basin. Deep Sea Research Part A, 38: 597-606.

PRICE G.D., FÕZY I., PÁLFY J., 2016 - Carbon cycle history through the Jurassic-Cretaceous boundary: a new global $\delta^{13} \mathrm{C}$ stack. Palaeogeography, Palaeoclimatology, Palaeoecology, 451: 46-61.

PURSER B.H., TUCKER M.E., ZENGER D.H., 1994 - Problems, progress and future research concerning dolomites and dolomitization. IAS Special Publications, 21: 3-20.

QUENSTEDT F.A., 1856-1858 - Der Jura. H. Laupp'sche Buchhandlung.

REICHART G.L., LOURENS L.J., ZACHARIASSE W.J., 1998 Temporal variability in the northern Arabian Sea oxygen minimum zone (OMZ) during the last 225,000 years. Paleoceanography, 13, 607-621.

REINHOLD C., 1998 - Multiple episodes of dolomitization and dolomite recrystallization during shallow burial in Upper Jurassic shelf carbonates: eastern Swabian Alb, southern Germany. Sedimentary Geology, 121: 71-95.

RUF M., LINK E., PROSS J., AIGNER T., 2003 - Integrated sequence stratigraphy: Facies, stable isotope and palynofacies analysis in a deeper epicontinental carbonate ramp (Late Jurassic, SW Germany). Sedimentary Geology, 175: 391-414.

SALLER A., 2006 - Geochemistry of meteoric calcite cements in some Pleistocene limestones. Sedimentology, 38: 601-621.

SCHARFENBERG L., 2011 - Mikrofaziesanalyse und Genese eines oberjurassischen Plattenkalkvorkommens von Wattendorf (Oberfranken) [Unpubl. Diploma Thesis]. University Erlangen. SCHOENHERR J., REUNING L., HALLENBERGER M., LÜDERS V., LEMMENS L, BIEHL B.C., LEWIN A., LEUPOLD M., WIMMERS K., STROHMENGER C.J., 2018 - Dedolomitiza- 
tion: review and case study of uncommon mesogenetic formation conditions. Earth-Science Reviews, 185: 780-805.

SCHWEIGERT G., 2015 - Biostratigraphie der Plattenkalke der südlichen Frankenalb. In: Solnhofen - ein Fenster in die Jurazeit (eds. G. Arratia et al.): 63-66. Verlag Dr. Friedrich Pfeil, München.

SEILACHER A., REIF W.E., WESTPHAL F., 1985 - Sedimentological, ecological and temporal patterns of fossil Lagerstätten. Philosophical Transactions of the Royal Society of London, B, 311: 5-23.

SHACKLETON N.J., KENNETT J.P., 1975 - Paleotemperature history of the Cenozoic and initiation of Antarctic glaciation: oxygen and carbon isotope analyses in DSDP sites 277, 279 and 281. Initial Reports of the Deep Sea Drilling Projects, 29: 743-756.

SIMO J.A., JOHNSON C.M., VANDREY M.R., BROWN, P.E., CASTROGIOVANNI E., DRZEWIECKI P.E., VALLEY J.W., BOYER J., 1994 - Burial dolomitization of the Middle Ordovician Glenwood Formation by evaporitic brines, Michigan Basin. Special Publications of the International Association of Sedimentologists, 21: 133-153.

STEVENS K., MUTTERLOSE J., SCHWEIGERT G., 2014 - Belemnite ecology and the environment of the Nusplingen Plattenkalk (Late Jurassic, southern Germany): evidence from stable isotope data. Lethaia, 47: 512-523.

VASCONCELOS C., MCKENZIE J.A., 1997 - Microbial mediation of modern dolomite precipitation and diagenesis under anoxic conditions (Lagoa Vermelha, Rio de Janeiro, Brazil). Journal of Sedimentary Research, 67: 78-390.

VASCONCELOS C., McKENZIE J.A., BERNASCONI S., GRUJIC D., TIENS A.J., 1995 - Microbial mediation as a possible mechanism for natural dolomite formation at low temperatures. Nature, 377: 20-22.
VIOHL G., 2015a - Der geologische Rahmen: die südliche Frankenalb und ihre Entwicklung. In: Solnhofen - ein Fenster in die Jurazeit (eds. G. Arratia et al.): 56-62. Verlag Dr. Friedrich Pfeil, München.

VIOHL G., 2015b - Die Plattenkalk-Typen der südlichen Frankenalb. In: Solnhofen - ein Fenster in die Jurazeit (eds. G. Arratia et al.): 72-77. Verlag Dr. Friedrich Pfeil, München.

VIOHL G., 2015c - Die lithographischen Plattenkalke im engeren Sinne. In: Solnhofen - ein Fenster in die Jurazeit (eds. G. Arratia et al.): 78-100. Verlag Dr. Friedrich Pfeil, München.

WIERZBOWSKI H., 2019 - Palaeoenvironmental changes recorded in the oxygen and carbon isotope composition of Kimmeridgian (Upper Jurassic) carbonates from central Poland. Geological Quarterly, 63: 359-374.

WIERZBOWSKI H., DUBICKA Z., RYCHLIŃSKI T., DURSKA E., OLEMPSKA E., BŁAŻEJOWSKI B., 2016 - Depositional environment of the Owadów-Brzezinki conservation Lagerstätte (uppermost Jurassic, central Poland): evidence from microfacies analysis, microfossils and geochemical proxies. Neues Jahrbuch für Geologie und Paläontologie Abhandlungen, 282: 81-108.

WIERZBOWSKI H., ANCZKIEWICZ R., PAWLAK J., ROGOV M.A., KUZNETSOV A.B., 2017 - Revised Middle-Upper Jurassic strontium isotope stratigraphy. Chemical Geology, 466: 239-255.

ZHENG Y.-F., 1999 - Oxygen isotope fractionation in carbonate and sulfate minerals. Geochemical Journal, 33: 109-126.

ZUO F., HEIMHOFER U., HUCK S., ADATTE T., EHRBACHER J., BODIN S., 2019 - Climatic fluctuations and seasonality during the Kimmeridgian (Late Jurassic): Stable isotope and clay mineralogical data from the Lower Saxony Basin, Northern Germany. Palaeogeography, Palaeoclimatology, $\mathrm{Pa}$ laeoecology, 517: 1-15. 